Hydrol. Earth Syst. Sci., 16, 423-440, 2012

www.hydrol-earth-syst-sci.net/16/423/2012/

doi:10.5194/hess-16-423-2012

(c) Author(s) 2012. CC Attribution 3.0 License.

\title{
Comparing soil moisture retrievals from SMOS and ASCAT over France
}

\author{
M. Parrens ${ }^{1}$, E. Zakharova ${ }^{1}$, S. Lafont ${ }^{1}$, J.-C. Calvet $^{1}$, Y. Kerr ${ }^{2}$, W. Wagner ${ }^{3}$, and J.-P. Wigneron ${ }^{4}$ \\ ${ }^{1}$ CNRM-GAME, URA1357, Météo-France, CNRS, Toulouse, France \\ ${ }^{2}$ CESBIO, UMR5126, CNES/CNRS/IRD/UPS, Toulouse, France \\ ${ }^{3}$ Institute of Photogrammetry and Remote Sensing, Vienna University of Technology, Vienna, Austria \\ ${ }^{4}$ INRA, EPHYSE, Villenave d'Ornon, France
}

Correspondence to: J.-C. Calvet (jean-christophe.calvet@meteo.fr)

Received: 9 September 2011 - Published in Hydrol. Earth Syst. Sci. Discuss.: 21 September 2011

Revised: 2 February 2012 - Accepted: 3 February 2012 - Published: 9 February 2012

\begin{abstract}
The first products derived over France in 2010 from the L-band brightness temperatures $\left(T_{\mathrm{b}}\right)$ measured by the SMOS (Soil Moisture and Ocean Salinity) satellite, launched in November 2009, were compared with the surface soil moisture (SSM) estimates produced by the C-band Advanced Scatterometer, ASCAT, launched in 2006 on board METOP-A. SMOS and ASCAT SSM products were compared with the simulations of the ISBA-A-gs model and with in situ measurements from the SMOSMANIA network, including 21 stations located in southern France. ASCAT tended to correlate better than SMOS with ISBA-A-gs. The significant anomaly correlation coefficients between in situ observations and the SMOS (ASCAT) product ranged from 0.23 to 0.48 ( 0.35 to 0.96 ). However, in wet conditions, similar results between the two satellite products were found. An attempt was made to derive SSM from regressed empirical logarithmic equations using a combination of SMOS $T_{\mathrm{b}}$ at different incidence angles and different polarizations, and the Leaf Area Index (LAI) modeled by ISBA-A-gs. The analysis of the intercept coefficient of the regression showed an impact of topography. A similar analysis applied to ASCAT and SMOS SSM values showed a more limited impact of topography on the intercept coefficient of the SMOS SSM product, while fewer residual geographic patterns were found for the ASCAT SSM.
\end{abstract}

\section{Introduction}

Soil moisture plays a key role in the hydrological cycle and in land-atmosphere interactions. For example, evapotranspiration, infiltration and runoff are driven by soil moisture. A number of studies have shown the importance of soil moisture in many applications: atmospheric reanalyses and weather forecast (Beljaars et al., 1996; Frennessy and Shukla, 1999; Diermeyer, 2000), land surface and crop growth modelling (Diermeyer et al., 1999; Georgakakos and Carpenter, 2006; de Wit and van Diepen, 2007; Guerif and Duke, 2000), hydrometeorology (Eltahir, 1998, among others) and improvement of flood prediction (Brocca et al., 2010a).

Since the 1970s, remote sensing appears as a potential tool to access soil moisture at different temporal and spatial scales. Indeed, microwave remote sensing is able to provide quantitative information about the water content of a shallow near surface layer (Schmugge, 1983), particularly in the low-frequency microwave range, from 1 to $10 \mathrm{GHz}$. In the last few years, significant progress towards operational soil moisture monitoring has been made (Wagner et al., 2007).

Passive microwave remote sensing of soil moisture was addressed by many research programs. Various airborne and field campaigns were performed, showing the high potential of L-band $(\sim 1.4 \mathrm{GHz})$ measurements for the estimation of surface parameters (Skou, 1989; Raju et al., 1995; Chanzy et al., 1997; Wigneron et al., 1997; Wilson et al., 2001; Saleh et al., 2004; Calvet et al., 2011; Zribi et al., 2011; Albergel 
et al., 2011). Moreover, L-band is the optimal wavelength range to observe soil moisture as higher frequencies are more significantly affected by perturbing factors such as atmospheric effects and vegetation cover (Schumugge, 1983; Kerr et al., 2001). Apart from a few days of L-band radiometric observations on Skylab from June 1973 to January 1974 (Eagleman et al., 1976; Jackson et al., 2004), spaceborne microwave radiometers have been operating at frequencies above $5 \mathrm{GHz}$ because the satellite antenna size is directly proportional to the squared wavelength (Ulaby et al., 1982). Recent technological and scientific achievements permitted to develop the Soil Moisture and Ocean Salinity (SMOS) mission (Kerr et al., 2001, 2007) launched in November 2009. SMOS consists of a spaceborne L-band interferometric radiometer able to provide multiangular microwave polarimetric brightness temperatures $\left(T_{\mathrm{b}}\right)$, from which a surface soil moisture (SSM) product is derived. Wigneron et al. (1995, 2003) have shown the possibility to retrieve biophysical variables, including SSM, from bipolarized and multiangular microwave $T_{\mathrm{b}}$. The core component of the SMOS soil moisture retrieval algorithm is the L-band Microwave Emission of the Biosphere (L-MEB) model which simulates the microwave emission at L-band from the soil-vegetation layer (Pellarin et al., 2003b; Wigneron et al., 2007; Kerr, 2010; Panciera et al., 2009). The main difficulty in the estimation of soil moisture using microwave radiometry arises from the presence of a dense overlying vegetation: the vegetation layer attenuates the soil emission and adds its own emission to the soil emission. Also, the presence of water bodies and of a marked topography may alter the SSM retrieval (Pellarin et al., 2003a,c; Mialon et al., 2008, respectively).

Microwave instruments operating at C-band (close to the L-band), either passive or active, are the Advanced Microwave Scanning Radiometer for the Earth Observing System (AMSR-E on the Aqua satellite), WindSAT (a microwave radiometer on the Coriolis satellite), and the scatterometer on board the European Remote Sensing Satellite (ERS-1, ERS-2). Finally, ASCAT (Advanced Scatterometer) has been orbiting on the METOP meteorological satellite of EUMETSAT since 2006, with a spatial resolution close to SMOS, and C-band radar backscatter measurements at 5.255 GHz (Wagner et al., 2007b; Bartalis et al., 2007a,b). ASCAT was found to accurately reproduce the temporal dynamics of the surface soil moisture measured in situ, or simulated, across different areas in Europe (Albergel et al., 2009, 2010; Brocca et al., 2010b).

Microwave satellite-derived soil moisture products can be retrieved from different microwave remote sensing observations and they need to be verified through in situ soil moisture observations (Rüdiger et al., 2009). Relatively few in situ soil moisture networks are operative now. The International Soil Moisture Network (Dorigo et al., 2011) now gathers data from many stations around the globe (www.ipf.tuwien.ac.at/ insitu/), including those from the SMOSMANIA (Soil Moisture Observing System, Meteorological Automatic Network
Integrated Application) stations. Since 2006, in southwestern France, the SMOSMANIA network (Calvet et al., 2007; Albergel et al., 2008) has been measuring soil moisture at different depths. It was extended in 2009 with nine new stations located in southeastern France. As the SMOS products are new, they need to be validated with in situ observations, and compared with other satellite products which have more maturity. Moreover, Albergel et al. (2010) showed that SSM values simulated by the ISBA land surface model (LSM) compare well with the SMOSMANIA in situ observations and with the ASCAT SSM.

In this study, the first SMOS Level 2 product (SMOSL2 SSM), covering the year 2010, is compared with the SMOSMANIA SSM, together with the ASCAT SSM. The SMOS vs. ASCAT benchmarking is then extended to the whole France domain, using as a reference a set of SSM simulations performed by a version of the ISBA LSM (ISBAA-gs) able to simulate SSM, together with the vegetation biomass and Leaf Area Index (LAI), at a spatial resolution of $8 \mathrm{~km} \times 8 \mathrm{~km}$.

Finally, it is shown that the use of the SMOS Level 1 product (SMOS-L1 $T_{\mathrm{b}}$ ) permits to investigate the factors affecting the accuracy of the retrieved SSM. Indeed, previous studies have shown that semi-empirical regression equations based on $T_{\mathrm{b}}$ observations can be used to retrieve SSM (Wigneron et al., 2004; Saleh et al., 2006; Calvet et al., 2011). This approach is based on statistical relationships, calibrated from simulated or observed datasets, which require $T_{\mathrm{b}}$ at two distinct incidence angles and/or two polarizations. It was successfully applied to SMOS-L1 data by Albergel et al. (2011). In this study, the SMOS-L1 data are used to estimate SSM based on regression coefficients determined using either SMOSMANIA or the ISBA-A-gs SSM for the year 2010 .

The various data sets used in this study are presented in Sect. 2, together with the statistical methods used to analyze the data. Section 3 presents the results and Sect. 4 summarizes a discussion of the main findings. Finally, the main conclusions are presented in Sect. 5.

\section{Material and methods}

\subsection{Satellite data}

In this study, the L1 and L2 SMOS products ( $T_{\mathrm{b}}$ and SSM, respectively) are investigated for the year 2010, together with the ASCAT SSM.

\subsubsection{The SMOS products}

The SMOS mission is a joint program of the European Space Agency (ESA), the Centre National d'Etudes Spatiales (CNES), and the Centro para el Desarrollo Tecnológico Industrial (CDTI), in the framework of the Earth Explorer Opportunity Mission initiative. Over land, the aim of SMOS is 
to provide global SSM maps with an accuracy better than $0.04 \mathrm{~m}^{3} \mathrm{~m}^{-3}$, a spatial resolution better than $50 \mathrm{~km}$, every three days. Also, the vegetation water content can be estimated with an accuracy of $0.5 \mathrm{~kg} \mathrm{~m}^{-2}$ every six days (Kerr et al., 2001). The SMOS instrument is a L-band $(21 \mathrm{~cm}$, $1.42 \mathrm{GHz}$ ) 2-D interferometric radiometer. At L-band, the atmospheric contribution to the signal is limited, and clouds and atmospheric water content have negligible effects (Kerr and al., 1993). Moreover, L-band is more sensitive to soil moisture than higher frequencies over vegetated areas (Schmugge, 1998; Wigneron et al., 1995; Calvet et al., 2011).

SMOS has a sun-synchronous orbit at $757 \mathrm{~km}$ altitude $( \pm 1 \mathrm{~km})$ with a 06:00 Local Standard Time (LST) $\pm 15 \mathrm{~min}$ ascending equator crossing time. This time was chosen in order to minimize factors impacting soil moisture retrieval, such as vertical soil-vegetation temperature gradients, and the Faraday rotation in the ionosphere. A two-dimensional picture is generated by SMOS every $2.4 \mathrm{~s}$. The average ground resolution is $43 \mathrm{~km}$ and the globe is fully imaged every three days at 06:00 and 18:00 LST. The radiometric sensitivity of SMOS radiometer over land is $3.5 \mathrm{~K}$ per snapshot at boresight (McMullan et al., 2009). The SMOS instrument measures the cross correlations between pairs of receivers to derive a visibility function. In a first approximation, the L-band $T_{\mathrm{b}}$ of the source is computed as the inverse Fourier transform of this function (McMullan et al., 2009). Finally, $T_{\mathrm{b}}$ is measured at several incidence angles, for two polarizations. It is important to note that the SMOS signal can be perturbed by man-made Radio Frequency Interferences (RFI) that degrade the scientific retrievals. Indeed, radio signals received in the L-band are sensitive to RFI (Njoku et al., 2005). Asia and Europe are particularly affected by this phenomenon (Oliva et al., 2012). In Europe, France is not the most affected country. However, Albergel et al. (2011) had to filter out about half of airborne $T_{\mathrm{b}}$ observations affected by RFI, over 11 sites in southwestern France. Two types of RFI were identified by Pardé et al. (2011) in southwestern France: pulsed RFI (due to radars, air traffic control or military installations) and continuous-wave RFI. The latter can trigger very high values of $T_{\mathrm{b}}$.

In this study, reprocessed data for the year 2010 were used. In a first stage, the SMOS-L1 $T_{\mathrm{b}}$ product was projected from the antenna ( $X, Y$ polarizations) to the Earth surface ( $H$ and $V$ polarizations) reference frame. The $T_{\mathrm{b} X}$ and $T_{\mathrm{b} Y}$ values were transformed into $T_{\mathrm{b} H}$ and $T_{\mathrm{b} V}$ values and corrected for Faraday rotation using an algorithm provided by the CESBIO team (http://www.cesbio.ups-tlse.fr/ SMOS_blog/wp-content/uploads/TOOLS/XY2HV.m). In order to remove the data contaminated by the most intense RFI, a filtering procedure was applied to the $T_{\mathrm{b}}$. First, all the $T_{\mathrm{b} H}$ and $T_{\mathrm{b} V}$ measurements were filtered for extreme values exceeding the median $T_{\mathrm{b}} \pm 50 \mathrm{~K}$, for each grid point at a given date. Second, we applied a locally weighted scatterplot smoothing technique, known as LOESS, or LOWESS filtering. It is based on fitting by a simple model the localized data subsets (Cleveland and Devil, 1988) in a predefined window. A window of $2.5^{\circ}$ was employed as it captured well most of the $T_{\mathrm{b}}$ aberrations caused by RFI. Third, bipolarized values of $T_{\mathrm{b}}$ were extracted for incidence angles $(\theta)$ of $20^{\circ}, 30^{\circ}, 40^{\circ}$ and $50^{\circ}$. For each value of $\theta$, a median $T_{\mathrm{b}}$ was calculated in the range of $\theta \pm 2^{\circ}$. Then, RFI perturbations were further filtered out. The RFI filtering criterion was based on halved first Stockes parameter calculated as $T_{\mathrm{b}} \mathrm{S} 1=0.5\left(T_{\mathrm{b} H}+T_{\mathrm{b} V}\right)$ (Kerr et al., 2007). The mean values of $T_{\mathrm{b}} \mathrm{S} 1$ were calculated for the full year 2010 over the France domain, and the $T_{\mathrm{b}}$ measurements out of a two standard deviation interval were considered to be contaminated by RFI. In spite of this processing, residual low RFI perturbations may remain in the data set.

The SMOS-L2 (SSM) product was extracted over the France domain. The L2 algorithm is complex and uses the polarization and multi-angular information delivered by SMOS. It involves direct model inversions and decision trees, and uses ancillary data such as air temperature, soil texture and land cover information.

In 2010, numerous technical and algorithm corrections were performed and affected both L1 and L2 products. In this study, new reprocessed L1 and L2 data, based on the same algorithm, were used. As recommended by Jackson (1980), only the ascending passes (between 04:00 and 07:00 LST over France) were used, because the soil is most likely to be in hydraulic near-equilibrium.

\subsubsection{The ASCAT soil moisture product}

ASCAT is a real aperture radar measuring radar backscatter with a very good radiometric accuracy and stability (Bartalis et al., 2007b). ASCAT uses $V V$ polarization at C-band. METOP has a sun-synchronous orbit, with equator crossing times of approximately 21:30 LST for the ascending overpass and 09:30 LST for the descending overpass. ASCAT observes $82 \%$ of the globe each day at a spatial resolution of $25-35 \mathrm{~km}$ (resampled to a $12.5 \mathrm{~km}$ grid). Measurements are performed on both sides of the satellite track, and two $550 \mathrm{~km}$ wide swaths of data are produced. This results in three independent backscatter measurements at different viewing angles and separated by a short time delay (Attema, 1991). In order to retrieve SSM, the backscattering coefficients are extrapolated to a reference angle at $40^{\circ}$, and scaled between the lowest and highest values measured over a long period (Wagner et al., 1999a,b,c). Using such a change detection approach, the obtained SSM value represents the degree of saturation of the topmost soil layer $(0.5 \mathrm{~cm}$ to $2 \mathrm{~cm})$, reported in percentage unit. This value is scaled between $0 \%$ (the minimum soil moisture) and $100 \%$ (the maximum soil moisture).

In this study, an updated ASCAT SSM dataset supplied by Vienna University of Technology (TU-Wien), resampled on a $12.5 \mathrm{~km}$ grid, was used. As for SMOS, only morning passes (between 08:00 and 11:00 LST over France) were considered. 

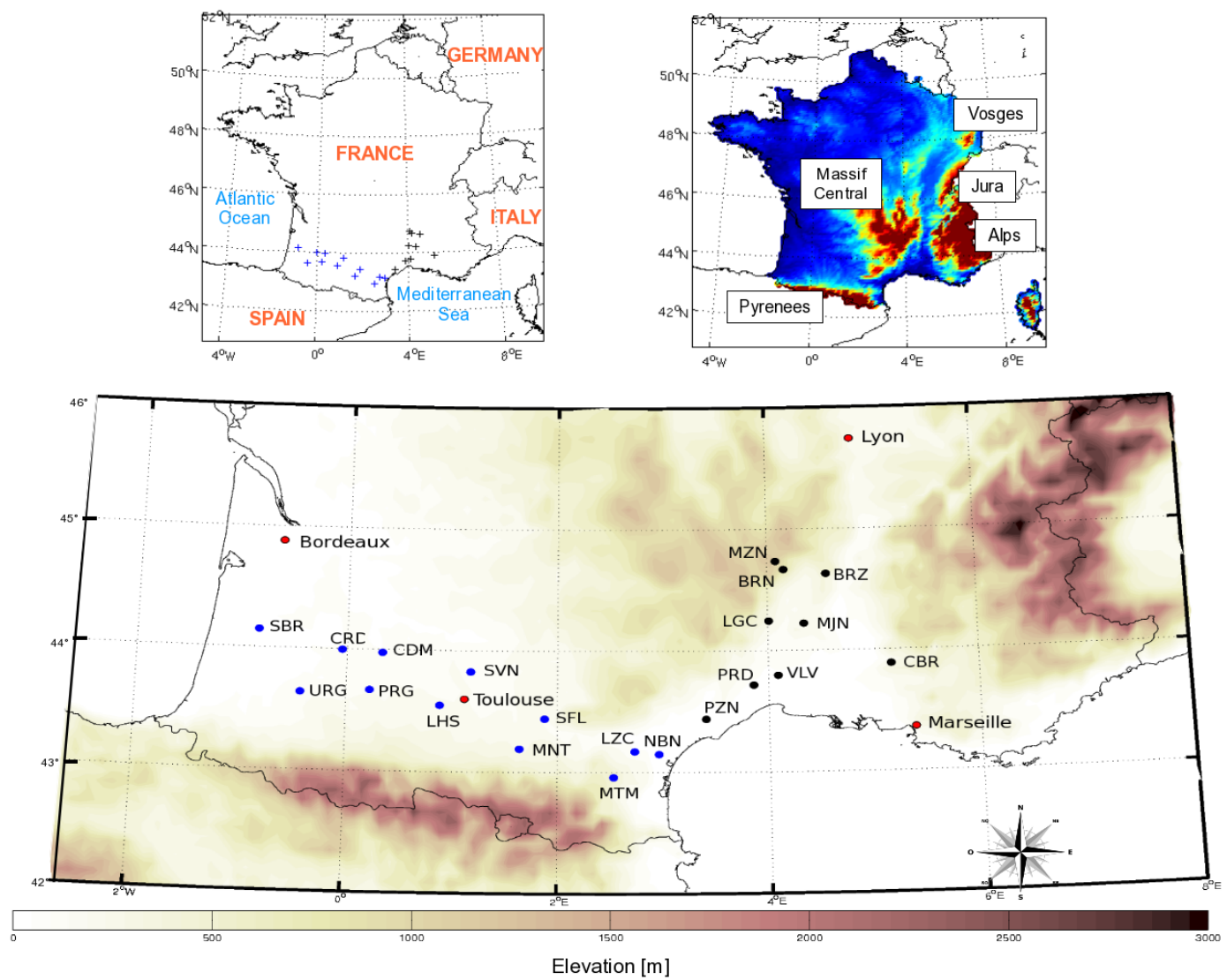

Fig. 1. The SMOSMANIA soil moisture network in southern France. The blue dots and crosses represent the 12 stations operational since 2007, the dark dots and crosses represent the new 9 stations operational since 2009. Topography is shown (bottom, top-right panel) together with the main mountainous areas (top-right panel).

\subsection{The SMOSMANIA network}

The main objective of the SMOSMANIA network is to verify remotely sensed and modeled soil moisture products. This network was designed to validate the SMOS SSM estimates (Calvet et al., 2007). SMOSMANIA is based on the existing automatic weather station network of Météo-France. Twenty-one stations were equipped with four soil moisture probes (ThetaProbe ML2X of Delta-T Devices), horizontally installed at depths of $5,10,20$ and $30 \mathrm{~cm}$, performing measurements at regular intervals of $12 \mathrm{~min}$. The SMOSMANIA SSM data are in units of $\mathrm{m}^{3} \mathrm{~m}^{-3}$.

Twelve stations were installed in 2006 in southwestern France, following a Mediterranean-Atlantic transect (Albergel et al., 2008). In 2008, the network was extended, with nine new stations located in the Mediterranean region (Fig. 1). Most of the stations are at low altitude and on reasonably flat terrains, with the exception of Barnas, La-GrandCombe, Mouthoumet, Berzème, and Mazan-Abbaye (BRN, LGC, MTM, BRZ, and MZN, respectively) at $480 \mathrm{~m}, 499 \mathrm{~m}$, $538 \mathrm{~m}, 650 \mathrm{~m}$, and $1240 \mathrm{~m}$ a.s.l. (above sea level), respectively. During the installation of soil moisture probes, soil samples were collected at the four depths of the soil moisture profile in order to calibrate the probe. The soil characteristics of the new stations, listed from East to West, are presented in Table 1.

Consistent with the SMOS morning passes used in this study, SMOSMANIA observations at a depth of $5 \mathrm{~cm}$, between 04:00 UTC and 07:00 UTC were used. For ASCAT, observations between 08:00 UTC and 11:00 UTC were used. For both SMOS and ASCAT, daily average SMOSMANIA morning SSM values were computed.

\subsection{The ISBA-A-gs LSM}

In the ISBA (Interactions between Surface, Biosphere, and Atmosphere, Noilhan and Planton, 1989; Noilhan and Mahfouf, 1996) LSM used in this study, the soil hydrology is based on the force restore approach, according to Deardorff (1978). The model represents two soil layers. The first layer includes the root-zone, represented by a bulk reservoir corresponding to the maximum rooting depth, and a representation of SSM associated to a skin soil top-layer ( $\sim 1 \mathrm{~cm}$ thick). The latter is used for the computation of the 
Table 1. Soil characteristics of the nine new stations of the SMOSMANIA network at four depths $(5,10,20$ and $30 \mathrm{~cm})$ : fractions of clay, sand fraction, organic matter, and bulk density. The station are listed from East to West (Pezenas to Cabrières d'Avignon).

\begin{tabular}{|c|c|c|c|c|c|}
\hline Stations & $\begin{array}{r}\text { Depth } \\
(\mathrm{cm})\end{array}$ & $\begin{array}{r}\text { Clay } \\
\left(\mathrm{g} \mathrm{kg}^{-1}\right)\end{array}$ & $\begin{array}{c}\text { Sand } \\
\left(\mathrm{g} \mathrm{kg}^{-1}\right)\end{array}$ & $\begin{array}{c}\text { Organic } \\
\text { matter } \\
\left(\mathrm{g} \mathrm{kg}^{-1}\right)\end{array}$ & $\begin{array}{c}\text { Bulk } \\
\text { density } \\
\left(\mathrm{kg} \mathrm{m}^{-3}\right)\end{array}$ \\
\hline \multicolumn{6}{|c|}{ Pézenas (PZN) } \\
\hline & 5 & 175 & 506 & 49.5 & 1238 \\
\hline & 10 & 174 & 519 & 23.2 & 1311 \\
\hline & 20 & 161 & 598 & 10.9 & 1266 \\
\hline & 30 & 194 & 520 & 11.5 & 1363 \\
\hline \multicolumn{6}{|c|}{ Prades-le-Lez (PRD) } \\
\hline & 5 & 311 & 270 & 54.9 & 1358 \\
\hline & 10 & 328 & 237 & 49.7 & 1317 \\
\hline & 20 & 323 & 238 & 39.8 & 1409 \\
\hline & 30 & 335 & 217 & 35.3 & 1570 \\
\hline \multicolumn{6}{|c|}{ La Grand Combe (LGC) } \\
\hline & 5 & 129 & 732 & 29.7 & 1536 \\
\hline & 10 & 129 & 748 & 21.8 & 1496 \\
\hline & 20 & 88 & 815 & 30.1 & 1507 \\
\hline & 30 & 139 & 740 & 24.1 & 1507 \\
\hline \multicolumn{6}{|c|}{ Mazan-Abbaye (MZN) } \\
\hline & 5 & 150 & 676 & 102 & 961 \\
\hline & 10 & 126 & 720 & 78.2 & 1330 \\
\hline & 20 & 129 & 696 & 68.7 & 1127 \\
\hline & 30 & 109 & 664 & 53.5 & 1257 \\
\hline \multicolumn{6}{|c|}{ Villevieille (VLV) } \\
\hline & 5 & 136 & 657 & 53.4 & 1116 \\
\hline & 10 & 124 & 678 & 26.9 & 1274 \\
\hline & 20 & 106 & 695 & 12.7 & 1419 \\
\hline & 30 & 118 & 671 & 14.9 & 1381 \\
\hline \multicolumn{6}{|c|}{ Barnas (BRN) } \\
\hline & 5 & 95 & 773 & 70.8 & 1427 \\
\hline & 10 & 71 & 804 & 59.8 & 1630 \\
\hline & 20 & 61 & 802 & 30.5 & 1310 \\
\hline & 30 & 112 & 767 & 22.4 & 1527 \\
\hline \multicolumn{6}{|c|}{ Méjannes-le-Clap (MJN) } \\
\hline & 5 & 162 & 455 & 121 & 1276 \\
\hline & 10 & 193 & 428 & 110 & 1276 \\
\hline & 20 & 257 & 347 & 106 & 1276 \\
\hline & 30 & 202 & 303 & 78.1 & 1276 \\
\hline \multicolumn{6}{|c|}{ Berzème (BRZ) } \\
\hline & 5 & 233 & 375 & 38.0 & 1094 \\
\hline & 10 & 264 & 346 & 32.6 & 1280 \\
\hline & 20 & 257 & 386 & 25.9 & 1394 \\
\hline & 30 & 264 & 340 & 25.7 & 1294 \\
\hline \multicolumn{6}{|c|}{ Cabrières d'Avignon (CBR) } \\
\hline & 5 & 242 & 476 & 44.9 & 1300 \\
\hline & 10 & 233 & 488 & 26.3 & 1310 \\
\hline & 20 & 216 & 561 & 23.1 & 1325 \\
\hline & 30 & 223 & 498 & 20.1 & 1353 \\
\hline
\end{tabular}

soil evaporation. This modelled SSM is used in this study. The second layer is a deep, sub-root soil layer contributing to evapotranspiration through capillarity rises (Boone et al., 1999). Moreover, an explicit multilayer snow model is used (Boone and Etchevers, 2001). The soil and vegetation parameters used by ISBA are derived from a global database of soils and ecosystems, ECOCLIMAP (Masson et al., 2003). In this study, a new version of the ECOCLIMAP dataset (Faroux et al., 2009) was used. It contains an updated classification of vegetation types over Europe and North Africa. Moreover, the ISBA-A-gs (Calvet et al., 1998) version of the LSM was used. It is able to simulate the diurnal cycle of carbon and water vapour fluxes, together with LAI and soil moisture. ISBA-A-gs was used "offline", i.e. without coupling the LSM with an atmospheric model. The atmospheric forcing was produced by SAFRAN (Système d'Analyse Fournissant des Renseignements Atmosphérique à la Neige, Durant et al., 1993) using information from the automatic, synoptic and climatological networks of Météo-France and a first guess from large scale operational weather prediction models. An optimal interpolation method was used to analyse surface atmospheric variables (Durand et al., 1999). The LSM was used at a spatial resolution of $8 \mathrm{~km} \times 8 \mathrm{~km}$ to produce daily estimates of SSM and soil temperature at 07:00 UTC, and of LAI.

\subsection{Data preparation}

\subsubsection{Soil moisture products}

In order to compare ASCAT, SMOS and ISBA-A-gs SSM values, the satellite products were projected to the ISBA-Ags $0.070^{\circ}$ resolution $(8 \mathrm{~km} \times 8 \mathrm{~km})$ grid. The original resampled SMOS and ASCAT grids are $0.146^{\circ} \times 0.135^{\circ}$ and $0.125^{\circ} \times 0.125^{\circ}$, respectively. The projection was made by assigning each SMOS (ASCAT) data to all the ISBA-A-gs grid cells within $0.18^{\circ}\left(0.15^{\circ}\right)$ using a nearest neighbor approach (Draper et al., 2011a). Before the SMOS data were projected on the ISBA-A-gs grid, observations with a data quality index greater than $30 \%$ were removed. Similarly, ASCAT values with an estimated soil moisture error greater than $30 \%$ were removed. For all the dates with ASCAT observations flagged as frozen soil, flooded surfaces or covered by snow, no ASCAT-SMOS comparison was performed. Moreover, for SMOS-L2 and ASCAT products, a static mask was applied to remove (i) urban regions, identified as having an urban fraction greater than $15 \%$ in the ECOCLIMAP database (ii) steep mountainous terrain, identified as having a topographic complexity flag provided with the ASCAT data greater than $15 \%$. Finally, in order to remove all the observations corresponding to soil freezing conditions, an additional filter was applied to all the products: all the observations corresponding to SAFRAN air temperatures smaller than $277 \mathrm{~K}$ were removed. 
In order to better capture the day to day variability of SSM, the seasonal cycle was removed by calculating monthly SSM anomalies (Albergel et al., 2009). The difference to the mean was calculated for a sliding window of five weeks (if there were at least five measurements during this period), and the difference was scaled to the standard deviation. For each soil moisture SSM estimate at day $(i)$, a period $F$ was defined, with $F=[i,-17 d, i+17 d]$ corresponding to a five week window. The anomaly $\Theta$ is dimensionless and it is given by:

$\Theta(i)=\frac{\operatorname{SSM}(i)-\overline{\operatorname{SSM}(F)}}{\operatorname{Stdev}(\operatorname{SSM}(F))}$.

This equation was used to compute SSM anomalies from ASCAT, SMOS, ISBA-A-gs, and in-situ observations.

\subsubsection{Analysis of the SMOS-L1 $T_{b}$ data}

For SMOS-L1, the same static mask applied for SMOS-L2 and ASCAT (see Sect. 2.4.1) was used. In addition to the RFI filtering procedure described in Sect. 2.1.1, the dynamic SMOS-L2 flag was applied to SMOS-L1. As SSM values are considered in this study, the SMOS-L1 $T_{\mathrm{b}}$ were transformed into SSM values, using a simple regression technique based on semi-empirical statistical relationships between reference SSM values and $T_{\mathrm{b}}$ values at two contrasting incidence angles and/or two polarizations (Wigneron et al., 2004; Saleh et al., 2006b; Calvet et al., 2011; Albergel et al., 2011). Mattar et al. (2012) showed that an additional information on the vegetation development (such as the Normalized Difference Vegetation Index (NDVI), or the LAI) can improve the regression. In this study, a regression equation based on two incidence angles $\left(\theta_{1}\right.$ and $\left.\theta_{2}\right)$, two polarizations ( $p$ and $\left.q\right)$ and LAI estimates was used (adapted from Mattar et al., 2012):

$$
\begin{aligned}
& \mathrm{SSM}=\exp \left(A \ln \left(1-\frac{T_{\mathrm{b}}\left(\theta_{1, p}\right)}{T_{\mathrm{eff}}}\right)\right. \\
& +B \ln \left(1-\frac{T_{\mathrm{b}}\left(\theta_{1, q}\right)}{T_{\mathrm{eff}}}\right)+C \ln \left(1-\frac{T_{\mathrm{b}}\left(\theta_{2, p}\right)}{T_{\mathrm{eff}}}\right) \\
& \left.+D \ln \left(1-\frac{T_{\mathrm{b}}\left(\theta_{2, q}\right)}{T_{\mathrm{eff}}}\right)+E \mathrm{LAI}+F\right) .
\end{aligned}
$$

In Eq. (2), the LAI and the SSM are derived from reference ISBA-A-gs LSM simulations or, in the case of SSM, from SMOSMANIA SSM observations. The $T_{\text {eff }}$ symbol corresponds to the effective soil temperature affecting the land surface emission at L-band. In this study, $T_{\text {eff }}$ is derived from the surface temperature computed by the ISBA-A-gs model. The regression coefficients $A, B, C, D, E$ and $F$ vary from one grid cell to another and depend on surface characteristics (Saleh et al., 2006).
Also, a regression analysis was applied to the SMOS-L2 SSM:

$\mathrm{SSM}=A^{\prime} \mathrm{SSM}_{\mathrm{SMOS}}+B^{\prime}$

and to ASCAT data:

$\mathrm{SSM}=A^{*} \mathrm{SSM}_{\mathrm{ASCAT}}+B^{*}$.

In Eqs. (3) and (4), the reference SSM values were derived from ISBA-A-gs LSM simulations. In Eq. (4) the SSM simulated by ISBA-A-gs was rescaled between field capacity and wilting point values in order to be consistent with the ASCAT SSM. As for SMOS-L1 $T_{\mathrm{b}}$ in Eq. (2), the regression coefficients $A^{\prime}, B^{\prime}$, and $A^{*}$ and $B^{*}$ of Eqs. (3) and (4), respectively, vary from one grid-cell to another.

\subsubsection{Subset score analysis}

Separate analyses were performed for contrasting vegetation and soil moisture conditions, for the three main surface types in France: crops, forests (either broadleaf or coniferous) and grasslands. A $8 \mathrm{~km} \times 8 \mathrm{~km}$ grid cell was considered as representative of a given vegetation type (either crops, forests or grasslands), when the fraction of this vegetation type given by the ECOCLIMAP database was greater than $50 \%$. The LAI variable was chosen to characterize vegetation conditions. In the ISBA-A-gs simulations used in this study, the median LAI value was $1.66 \mathrm{~m}^{2} \mathrm{~m}^{-2}$. Under (over) this value, the vegetation was considered as sparse (dense). The rootzone soil moisture was used to distinguish dry from wet soil conditions. In order to account for the different soil types represented by ISBA-A-gs, the root-zone soil moisture $\left(\mathrm{m}^{3} \mathrm{~m}^{-3}\right)$ was converted into dimensionless units by scaling by the soil moisture at saturation. The resulting scaled soil moisture ranged between 0 and 1 . The median value of the simulated normalized root-zone soil moisture was 0.60 . Under (over) this value the soil was considered as dry (wet).

\section{Results}

\subsection{Comparison between SMOS and ASCAT SSM products}

SMOS and ASCAT SSM products were evaluated using the SMOSMANIA in situ observations in southern France, and the ISBA-A-gs SSM simulations over the whole of France, for the year 2010 .

\subsubsection{Comparison at the SMOSMANIA stations in southern France}

Statistical scores for the comparison between SMOS and ASCAT SSM anomalies and in situ SSM anomalies were determined. As described in Sect. 2.4.1, the satellite data were projected onto the ISBA-A-gs grid, and the SMOS and ASCAT time series for each SMOSMANIA site were taken 
Table 2. Comparison of SMOS-L2 and ASCAT SSM anomalies with the in-situ SSM $(-5 \mathrm{~cm})$ anomaly measured at 21 ground stations for the year 2010: correlation $\left(r_{\text {ano }}\right)$, mean bias (in-situ minus satellite products), root mean square error (RMSE) and p-value. The number of data used to calculate the scores is given $\left(n_{\mathrm{ano}}\right)$. Absolute correlations $\left(r_{\mathrm{abs}}\right)$ are indicated. NS stands for non significant, and $*$, **, $* * *$ stand for p-values greater than 0.05 , between 0.05 and 0.001 , and between 0.001 and 0.0001 , respectively.

\begin{tabular}{|c|c|c|c|c|c|c|c|c|c|c|c|c|c|c|c|c|}
\hline \multirow[b]{3}{*}{ Stations } & \multicolumn{8}{|c|}{ SMOS-L2 } & \multicolumn{8}{|c|}{ ASCAT } \\
\hline & \multicolumn{3}{|c|}{ Absolute correlations } & \multicolumn{5}{|c|}{ Anomalies } & \multicolumn{3}{|c|}{ Absolute correlations } & \multicolumn{5}{|c|}{ Anomalies } \\
\hline & $n_{\mathrm{abs}}$ & $r_{\mathrm{abs}}$ & P-value & $n_{\text {ano }}$ & $r_{\text {ano }}$ & RMSE & Bias & P-value & $n_{\mathrm{abs}}$ & $r_{\mathrm{abs}}$ & P-value & $n_{\text {ano }}$ & $r_{\text {ano }}$ & RMSE & Bias & P-value \\
\hline SBR & 6 & 0.06 & NS & 5 & 0.69 & 0.81 & -0.41 & NS & 158 & 0.82 & $* * *$ & 153 & 0.74 & 0.68 & 0.05 & $* * *$ \\
\hline URG & 122 & 0.61 & $* * *$ & 116 & 0.32 & 1.08 & 0.06 & $* *$ & 149 & 0.75 & $* * *$ & 139 & 0.65 & 0.71 & -0.06 & $* * *$ \\
\hline CRD & 119 & 0.55 & $* * *$ & 113 & 0.27 & 1.25 & 0.06 & $* *$ & 165 & 0.77 & $* * *$ & 153 & 0.53 & 0.96 & 0.01 & $* * *$ \\
\hline PRG & 134 & 0.53 & $* * *$ & 127 & 0.23 & 1.20 & 0.03 & $*$ & 153 & 0.77 & $* * *$ & 143 & 0.51 & 0.90 & -0.07 & $* * *$ \\
\hline $\mathrm{CDM}$ & 131 & 0.42 & $* * *$ & 126 & 0.25 & 1.17 & 0.05 & $* *$ & 164 & 0.71 & $* * *$ & 152 & 0.63 & 0.80 & -0.02 & $* * *$ \\
\hline LHS & 133 & 0.47 & $* * *$ & 128 & 0.29 & 1.11 & -0.15 & $* *$ & 152 & 0.63 & $* * *$ & 140 & 0.45 & 0.91 & -0.10 & $* * *$ \\
\hline SVN & 130 & 0.48 & $* * *$ & 123 & 0.39 & 1.06 & -0.01 & $* * *$ & 154 & 0.61 & $* * *$ & 142 & 0.45 & 0.91 & -0.11 & $* * *$ \\
\hline MNT & 118 & 0.39 & $* * *$ & 116 & 0.48 & 0.91 & -0.03 & $* * *$ & 151 & 0.64 & $* * *$ & 141 & 0.52 & 0.88 & -0.07 & $* * *$ \\
\hline SFL & 135 & 0.42 & $* * *$ & 129 & 0.38 & 1.00 & 0.02 & $* * *$ & 155 & 0.58 & $* * *$ & 143 & 0.38 & 0.97 & -0.04 & $* * *$ \\
\hline MTM & 102 & 0.34 & $* *$ & 97 & 0.20 & 1.13 & 0.11 & NS & 149 & 0.14 & NS & 140 & 0.12 & 1.15 & -0.05 & NS \\
\hline LZC & 23 & 0.59 & $* *$ & 17 & 0.60 & 0.83 & 0.03 & $*$ & 33 & 0.92 & $* * *$ & 23 & 0.96 & 0.33 & 0.08 & $* * *$ \\
\hline $\mathrm{NBN}$ & 118 & 0.53 & $* * *$ & 113 & 0.34 & 1.13 & 0.05 & $* *$ & 152 & 0.65 & $* * *$ & 142 & 0.37 & 1.07 & 0.05 & $* * *$ \\
\hline PZN & 116 & 0.52 & $* * *$ & 112 & 0.36 & 1.01 & -0.03 & $* * *$ & 167 & 0.76 & $* * *$ & 160 & 0.58 & 0.80 & -0.07 & $* * *$ \\
\hline PRD & 79 & 0.54 & $* * *$ & 69 & 0.39 & 1.02 & 0.03 & $* *$ & 142 & 0.42 & $* * *$ & 137 & 0.46 & 1.00 & -0.01 & $* * *$ \\
\hline LGC & 39 & 0.35 & $*$ & 26 & 0.17 & 1.14 & -0.06 & NS & 143 & 0.62 & $* * *$ & 137 & 0.65 & 0.82 & -0.04 & $* * *$ \\
\hline MZN & 40 & 0.48 & $* *$ & 36 & 0.38 & 1.01 & 0.05 & $*$ & 120 & 0.19 & $*$ & 114 & 0.35 & 0.98 & -0.03 & $* * *$ \\
\hline VLV & 95 & 0.61 & $* * *$ & 90 & 0.30 & 1.07 & 0.14 & $* *$ & 162 & 0.52 & $* * *$ & 155 & 0.70 & 1.01 & -0.08 & $* * *$ \\
\hline BRN & 12 & 0.44 & NS & 8 & 0.33 & 1.02 & 0.19 & NS & 64 & 0.58 & $* * *$ & 58 & 0.55 & 0.91 & 0.10 & $* * *$ \\
\hline MJN & 55 & 0.40 & $* *$ & 46 & 0.36 & 0.99 & -0.04 & $*$ & 134 & 0.68 & $* * *$ & 126 & 0.70 & 0.77 & -0.11 & $* * *$ \\
\hline BRZ & 47 & 0.53 & $* * *$ & 40 & 0.44 & 1.06 & 0.19 & $* *$ & 135 & 0.57 & $* * *$ & 132 & 0.69 & 0.81 & 0.02 & $* * *$ \\
\hline CBR & 74 & 0.51 & $* * *$ & 70 & 0.41 & 0.92 & 0.12 & $* *$ & 167 & 0.46 & $* * *$ & 157 & 0.44 & 0.97 & 0.11 & $* * *$ \\
\hline
\end{tabular}

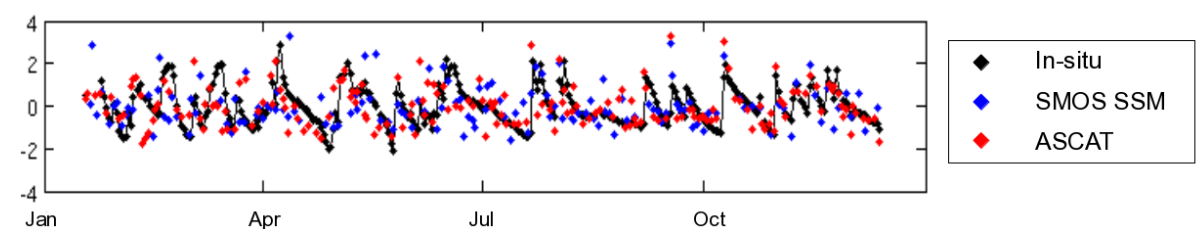

Fig. 2. Observed SSM anomalies at the Montaut (MNT) station in 2010, derived from (black) in situ measurements at a $5 \mathrm{~cm}$ depth, (blue) SMOS-L2, (red) ASCAT.

from the corresponding ISBA-A-gs grid cell. Albergel et al. (2011) assessed the consistency between SMOS-L1 data, airborne L-band radiometry observations, and the SMOSMANIA in situ observations at 11 stations. They found a good agreement of SMOS-L1 data with the other data sets for 9 of the 11 stations. In particular, very good results were obtained for the Montaut (MNT) station. Figure 2 presents anomaly time series from in situ measurements, SMOS SSM and ASCAT SSM at the MNT station for 2010. Most peaks and troughs are represented well. The SSM anomaly statistical scores are presented in Table 2 for SMOS ascending orbits and for ASCAT descending orbits. While significant correlations $\left(r_{\mathrm{ano}}\right)$ are found for 20 stations for ASCAT, 17 stations show significant $r_{\text {ano }}$ values for SMOS. For the stations showing significant SSM $r_{\text {ano }}$ values, the SMOS (ASCAT) $r_{\text {ano }}$ range from 0.23 to 0.60 (0.35 to 0.96 ), with an average value of $0.36(0.55)$. For both SMOS and ASCAT, the highest $r_{\text {ano }}$ between satellite SSM anomalies and in situ SSM anomalies, are observed for the Lézignan-Corbières (LZC) station. However, for this station, 2010 measurements are available from January to March and in November, only. These months correspond to wet periods including many rain events triggering marked SSM changes, and this can explain the better correlation.

The SMOS and ASCAT RMSE values range from 0.83 to 1.25 , and from 0.33 to 1.07 , respectively, with average values of 1.05 and 0.86 , respectively, in units of standard deviation. Finally, the SMOS and ASCAT biases range from -0.15 to 0.19 , and from -0.11 to 0.11 , respectively, with average values of 0.03 and -0.03 , respectively. For the stations associated to significant correlations, no systematic dry or wet SSM anomaly bias is observed.

For ASCAT, the MTM station, only, presents nonsignificant $r_{\text {ano }}$ values. MTM is situated close to a forested 

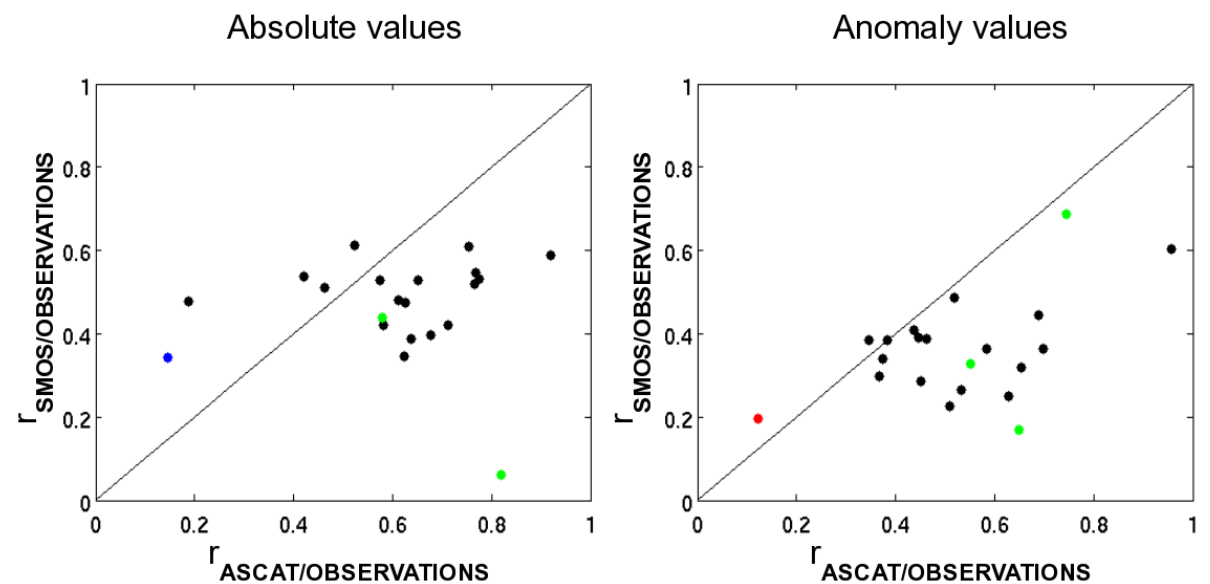

Fig. 3. SMOS-L2 vs. ASCAT SSM (left panel) absolute and (right panel) anomaly correlation coefficients with the SMOSMANIA in situ observations for each SMOSMANIA station. Black dots represent significant SSM correlations for both SMOS and ASCAT. Green dots represent significant SSM correlations for ASCAT, only. The blue dot indicates a significant SSM correlation for SMOS, only. The red dot corresponds to the MTM station, presenting no significant correlation (p-value > 0.05) for either SMOS or ASCAT.

and mountainous area, and its location can explain the poor results. The SMOS SSM seems to be more affected by topography than ASCAT, as non-significant results are found for five stations (Sabres (SBR), MTM, LGC, MZN and BRN), three of which (MZN, BRN, and MTM) present among the highest altitudes of the SMOSMANIA stations $(1165 \mathrm{~m}$, $672 \mathrm{~m}$, and $499 \mathrm{~m}$, respectively).

Regarding absolute correlation ( $r_{\text {abs }}$ in Table 2), two stations (SBR and BRN) present non-significant $r_{\mathrm{abs}}$ values for SMOS, one for ASCAT (MTM). For the stations showing significant SSM $r_{\text {abs }}$ values, the SMOS (ASCAT) $r_{\text {abs }}$ range from 0.34 to 0.61 (0.19 to 0.82 ), with an average value of 0.49 (0.64). For SMOS and ASCAT, the highest $r_{\mathrm{abs}}$ is observed for Urgons (URG) and SBR, respectively. Overall, $r_{\text {abs }}$ values are higher than $r_{\text {ano }}$ values. Indeed, the absolute correlation is explained to a large extent by seasonal variations, which are suppressed in SSM anomalies. In particular, non-significant SMOS-L2 $r_{\text {ano }}$ values are observed for MTM and LGC, while they present significant $r_{\text {abs }}$ values.

Figure 3 presents SMOS-L2 vs. ASCAT SSM absolute and anomaly correlation coefficients with the in situ observations, for the 21 SMOSMANIA stations. In general, the ASCAT SSM correlates better than the SMOS SSM with the in situ observations. Four stations present better significant $r_{\text {abs }}$ values for SMOS-L2: Prades-le-Lez (PRD), MZN, Villevieille (VLV), and Cabrières d'Avignon (CBR). On the other hand, only one station (MZN) presents better significant $r_{\text {ano }}$ values for SMOS-L2.

\subsubsection{Comparison over France using SSM values simulated by ISBA-A-gs}

Simulations of SSM values by the ISBA-A-gs LSM were used to generalize the SMOS vs. ASCAT benchmarking results found at the SMOSMANIA stations to other locations in France. In order to compare the satellite products with ISBA-A-gs, statistical scores were calculated for each grid cell of the ISBA-A-gs simulations. Figure 4 shows maps of anomaly correlation, RMSE and p-value between the SMOS and ASCAT SSM and the SSM calculated by ISBA-A-gs over France for the year 2010. In these maps, only significant values are plotted ( $\mathrm{p}$-value $<0.05$ ). The significant anomaly correlations range from $r_{\text {ano }}=0.24$ to 0.69 for SMOS and from $r_{\text {ano }}=0.24$ to 0.85 for ASCAT. On average, ASCAT presents better anomaly scores than SMOS, with average values of $r_{\mathrm{ano}}$, RMSE and mean bias of $0.65,0.78$, and -0.01 , respectively, against $0.40,1.04$, and 0.07 , respectively, for SMOS.

Figure 5 presents SMOS vs. ASCAT SSM anomaly correlation coefficients with the ISBA-A-gs simulations, for the France domain. Only significant correlations ( $\mathrm{p}$ value $<0.05$ ) are shown. The ISBA-A-gs grid cells corresponding to the SMOSMANIA stations are indicated, and more marked differences than those shown by Fig. 3 using SMOSMANIA data are found, with systematically higher ASCAT $r_{\text {ano }}$ values. In Fig. 5, the $r_{\text {ano }}$ values are calculated for the whole 2010 year. In terms of anomaly correlation with the ISBA-A-gs model, ASCAT performs better than SMOS-L2 for $99 \%$ of the grid cells. For few areas in the Champagne region $\left(48.81^{\circ} \mathrm{N}, 4.02^{\circ} \mathrm{E}\right)$ and close to Narbonne $\left(42.85^{\circ} \mathrm{N}, 2.58^{\circ} \mathrm{E}\right)$ SMOS-L2 performs better than ASCAT.

In order to investigate possible seasonal changes in the relative consistency of SMOS and ASCAT with ISBA-A-gs, the $r_{\text {ano }}$ values were disaggregated following the subset analysis described in Sect. 2.4.3. Figure 6 shows the SMOS vs. ASCAT SSM anomaly correlation coefficients with the ISBAA-gs simulations, disaggregated in four vegetation and soil 

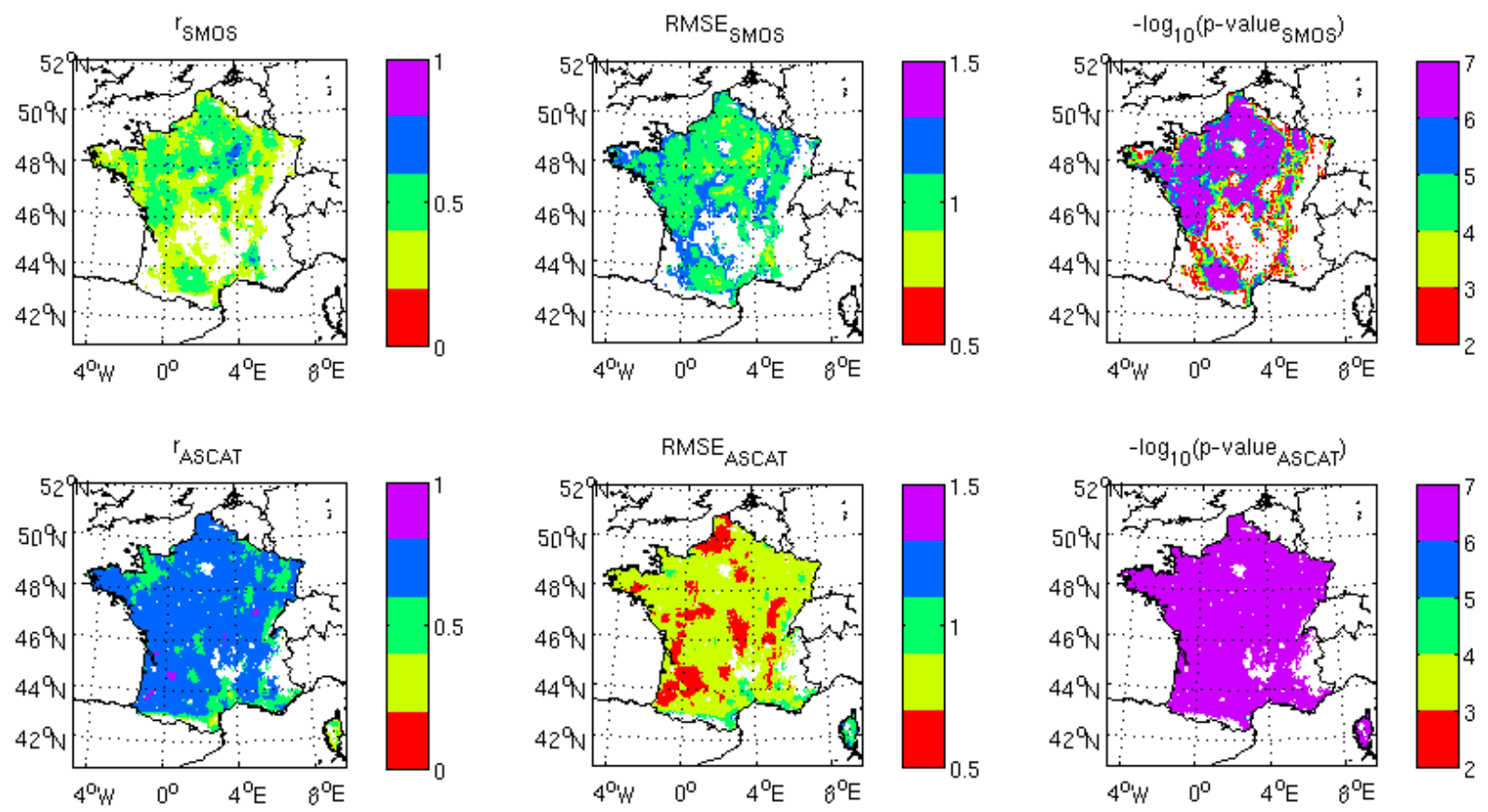

Fig. 4. Comparison between SMOS-L2 and ASCAT SSM anomalies with SSM anomalies calculated by ISBA-A-gs. From left to right: correlation coefficient $(r)$, root mean square error (RMSE), and p-value, for (top panel) SMOS-L2, and (bottom panel) ASCAT. Blanked areas are mountainous or urban areas and areas presenting a non-significant score (p-value $>0.05)$.

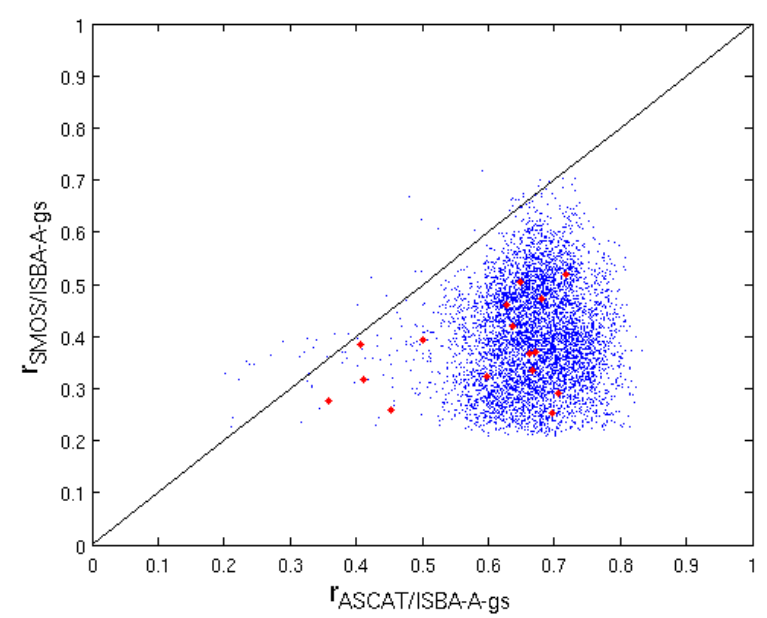

Fig. 5. SMOS-L2 vs. ASCAT SSM anomaly correlation coefficients with the ISBA-A-gs simulations for each ISBA-A-gs grid cell. Red dots represent the ISBA-A-gs grid-cells corresponding to SMOSMANIA stations. Only points presenting significant correlations (p-value < 0.05) for both SMOS-L2 and ASCAT are shown.

wetness classes, for each dominant cover type. Consistent with Fig. 5, ASCAT tends to outperform SMOS, but less systematically. Among the twelve sub-figures of Fig. 6, five present more than $40 \%$ of scores better for SMOS than for ASCAT. These cases correspond to forests (either sparse or dense) in wet conditions, sparse crops in wet conditions, sparse grasslands in dry conditions, and dense grasslands in wet conditions. Except for sparse grasslands and dense crops, SMOS tends to perform as well as ASCAT, in wet conditions. On the other hand, better agreement with ISBAA-gs SSM simulations is generally achieved by ASCAT in dry conditions.

\subsection{Soil moisture estimates derived from the SMOS $T_{b}$}

\subsubsection{At the SMOSMANIA stations in southern France}

In this section, the Eq. (2) empirical relationship is used to estimate SSM from SMOS-L1 data, using the SMOSMANIA in situ data as a reference for the determination of the correlation coefficients. The LAI values used in Eq. (2) are given by the average LAI simulated by ISBA-A-gs for the corresponding grid-cell. Table 3 presents the SSM estimate scores obtained using SMOS $T_{\mathrm{b}}$ values at incidence angles of $40^{\circ}$ and $20^{\circ}$. This particular biangular configuration presents the best score. The SSM estimates derived from Eq. (2) are significantly correlated to the observations ( $\mathrm{p}$-value $<0.05$ ) for 15 stations. Among stations with significant statistical scores, the correlation coefficients and the RMSE range from 0.65 to 0.89 and from $0.030 \mathrm{~m}^{3} \mathrm{~m}^{-3}$ to $0.082 \mathrm{~m}^{3} \mathrm{~m}^{-3}$, respectively. The average correlation coefficient and RMSE are 0.77 and $0.053 \mathrm{~m}^{3} \mathrm{~m}^{-3}$, respectively. For most SMOSMANIA stations located in southwestern France, the correlation scores are better than those obtained by Albergel et al. (2011). This is related to the use of LAI and of bipolarized 

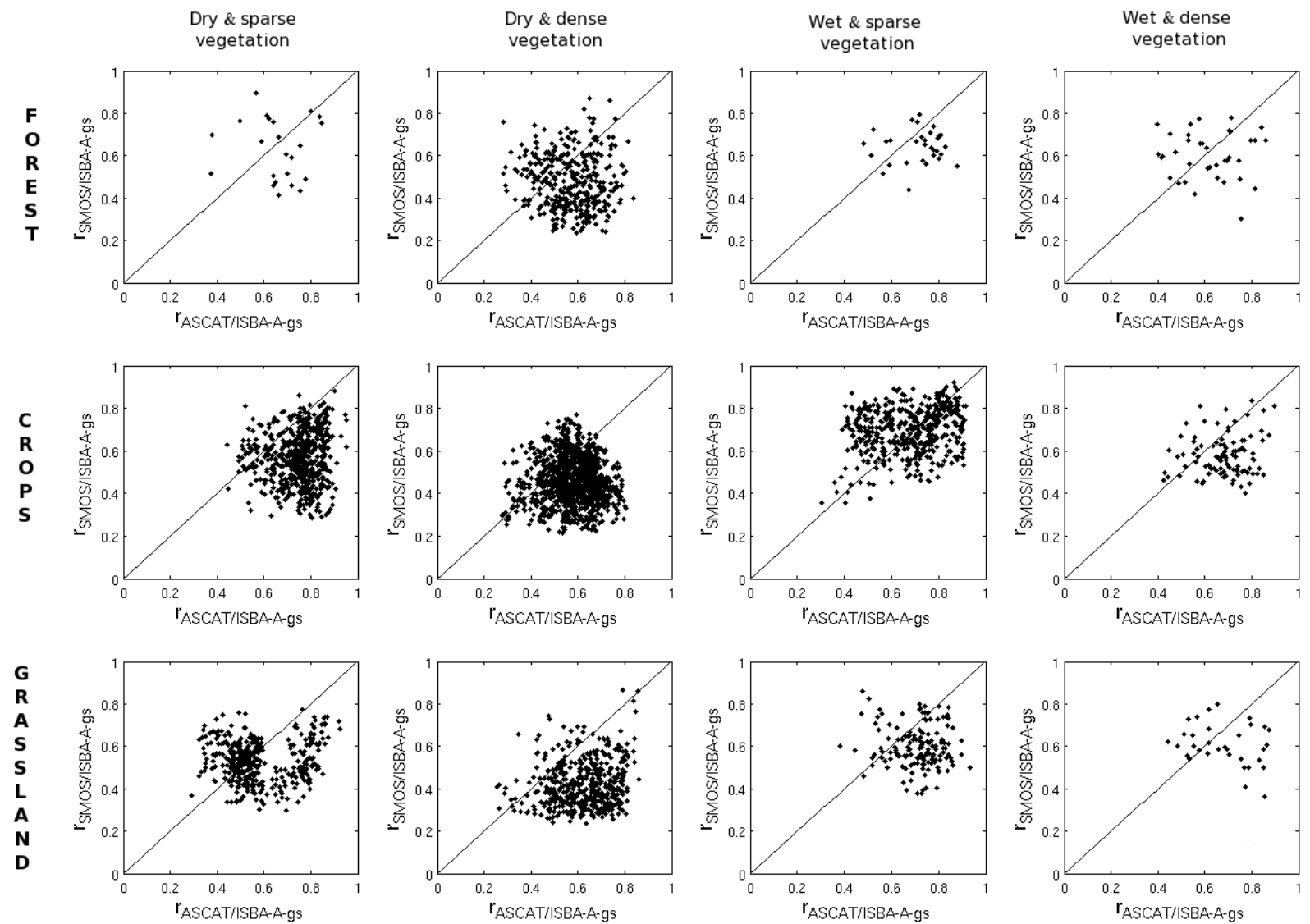

Fig. 6. Impact of vegetation density (dense and sparse) and soil wetness conditions (wet and dry) on SMOS-L2 vs. ASCAT SSM anomaly correlation coefficients with the ISBA-A-gs simulations for crops, forests, and grasslands.

$T_{\mathrm{b}}$ values at a low incidence angle $\left(20^{\circ}\right)$ as additional factors in this study, and to the use of reprocessed SMOS data. Note that for the 11 stations considered by Albergel et al. (2011), fewer observations are available in this study (from 31 to 50, against 44 to 107 in Albergel et al., 2011), because two $T_{\mathrm{b}}$ incidence angles are used.

Also, Table 3 presents the $A, B, C, D, E$ regression coefficient values and the $F$ intercept coefficient obtained in this configuration. They are specific to each site. They may depend on the soil and vegetation properties acting on the microwave emission, like soil roughness, soil surface infiltration and thermal properties, vegetation phenology and canopy structure. For all the stations, the $D$ coefficient, related to the $20 \mathrm{~V} T_{\mathrm{b}}$, is equal to zero. Therefore, only one term in $V$ polarization plays a role in the regression. Similar results are obtained with different incidence angles (not shown).

\subsubsection{Over France}

The same regression Eq. (2) with the same configuration (incidence angles of $20^{\circ}$ and $40^{\circ}$ ) as before, was applied using the ISBA-A-gs SSM over France instead of the in situ SSM for the estimation of the correlation coefficients. It produced a spatially distributed SMOS-L1 SSM. Moreover, the correlation between both SMOS-L2 and ASCAT SSM data with the ISBA-A-gs SSM was analyzed over France using Eqs. (3)-(4).

Figure 7 presents the score maps (correlation coefficient $r$ and RMSE) over France of Eqs. (2)-(4). Only significant values (p-value $<0.05$ ) were plotted. The average correlation coefficients over France for SMOS-L1, SMOS-L2, and ASCAT SSM are $0.45,0.49$, and 0.61 , respectively. The average RMSE values are $0.075 \mathrm{~m}^{3} \mathrm{~m}^{-3}, 0.072 \mathrm{~m}^{3} \mathrm{~m}^{-3}$, and 0.75 (dimensionless), respectively. The three SSM estimates correlate better with the ISBA-A-gs SSM in the western part of the country. The West to East decrease in correlation in particularly pronounced for SMOS-L1 and ASCAT. The RMSE follows the same behavior. It was checked that the number of satellite observations used in the regressions does not present this longitudinal contrast and that it has no influence on the obtained spatial patterns of the scores.

The regression coefficients over France for SMOS-L1, SMOS-L2 and ASCAT are presented in Fig. 8. For the SMOS-L1 SSM, derived from $T_{\mathrm{b}}$ values, the $B$ and $D$ coefficients (corresponding to $V$-polarized $T_{\mathrm{b}}$ ) tend to present values closer to zero than the $A$ and $C$ coefficients (corresponding to $H$-polarized $T_{\mathrm{b}}$ ). It must be noted that using 

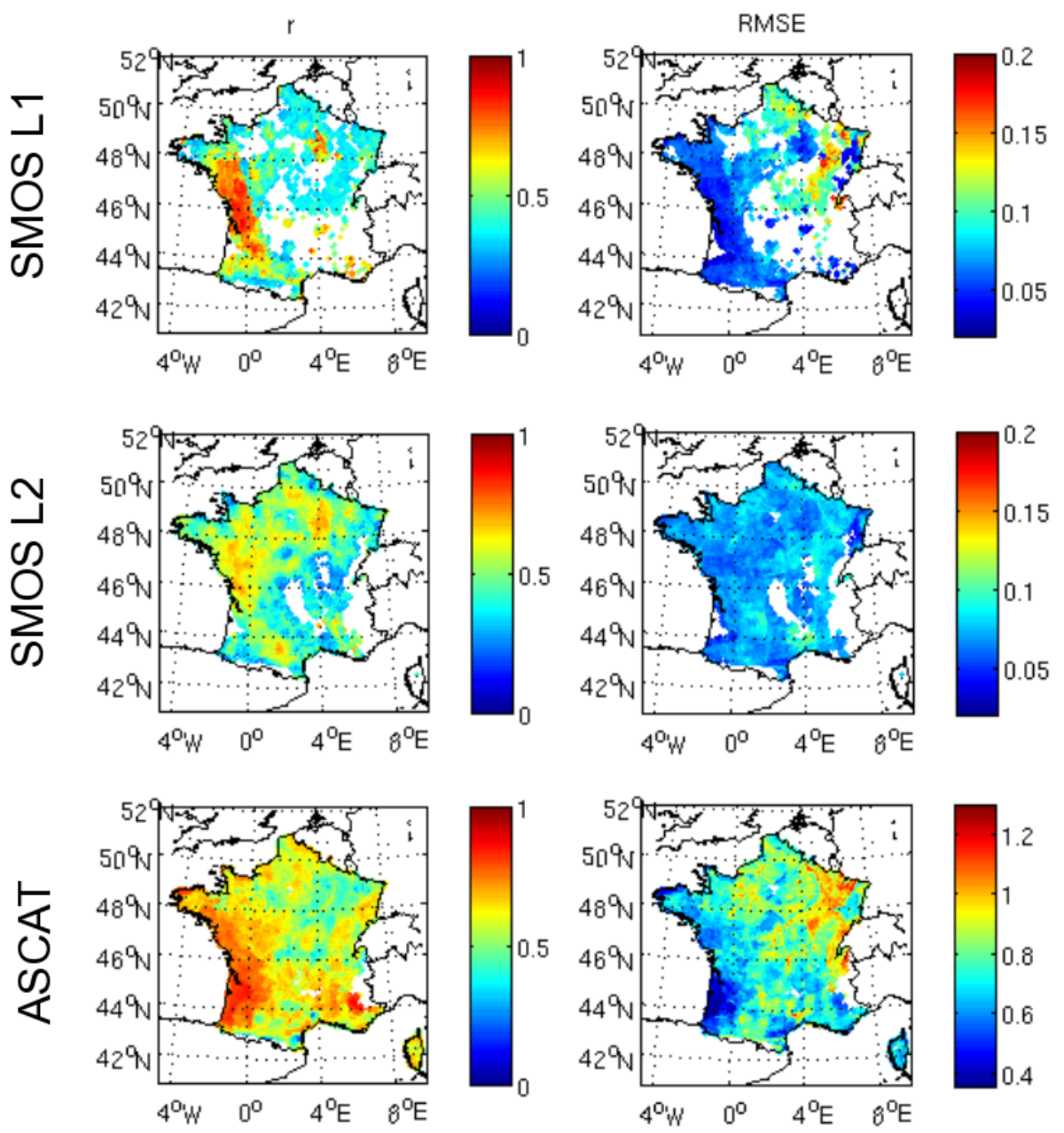

Fig. 7. Regression statistics of satellite vs. ISBA-A-gs SSM in 2010: (left panels) correlation coefficient ( $r$ ) and (right panels) root mean square error (RMSE), of (top panels) SMOS-L1 with Eq. (2), (middle panels) SMOS-L2 with Eq. (3), (bottom panels) ASCAT with Eq. (4). The RMSE is expressed in $\mathrm{m}^{3} \mathrm{~m}^{-3}$ in the dynamic range of ISBA-A-gs for SMOS, and in dimensionless units for ASCAT.

Eq. (2) without the LAI factor gives more weight to the $20 \mathrm{~V}$ $T_{\mathrm{b}}$ factor. This indicates that the $20 \mathrm{~V} T_{\mathrm{b}}$ may be linked with the vegetation opacity. In order to understand the spatial distribution of the coefficients, we searched analogies of their spatial patterns, with the spatial distribution of vegetation types and soil characteristics used by the LSM, and with the precipitation climatology, but no similarity was observed. Moreover, in western France, the $E$ regression coefficient of Eq. (2), relative to LAI, is close to zero while, on the other hand, LAI information is key in eastern France. The $F$ intercept coefficient presents analogies with the topography (Fig. 1). Low negative values of $F$ correspond to higher altitudes, and four French mountainous regions appear: part of the Pyrenees, Jura, Vosges and Massif Central. Note that most of the Alps area is flagged. The spatial correlation between altitude and $F$ values is $r=-0.51$. The possible spatial correlations between the parameters of Eq. (2) were investigated. The highest spatial correlations were btained between $A$ and $F\left(r^{2}=0.41\right)$, and between $A$ and $B\left(r^{2}=0.16\right)$. All the others squared correlation coefficients were lower than 0.09. Moreover, various configurations of Eq. (2) were tested, such as removing one, two, or three factors from the regression. The spatial distribution of the remaining coefficients were almost not affected. However, decreasing the number of terms of Eq. (2) tended to decrease the regression score and the percentage of grid cells obtaining a significant score. While Eq. (2) presents significant scores for $55 \%$ of the grid-cells, removing one, two, or three of the five factors reduced this fraction to $46 \%, 36 \%$, $31 \%$, on average, respectively.

For the SMOS-L2 SSM, a significant spatial correlation between altitude and values of the $B^{\prime}$ intercept coefficient is observed, also $(r=0.37)$. It is less marked than for the SMOS-L1 $F$ parameter, but data are not provided for the highest mountain ranges such as the Alps and part of the Pyrenees. For ASCAT, no correlation between the altitude 


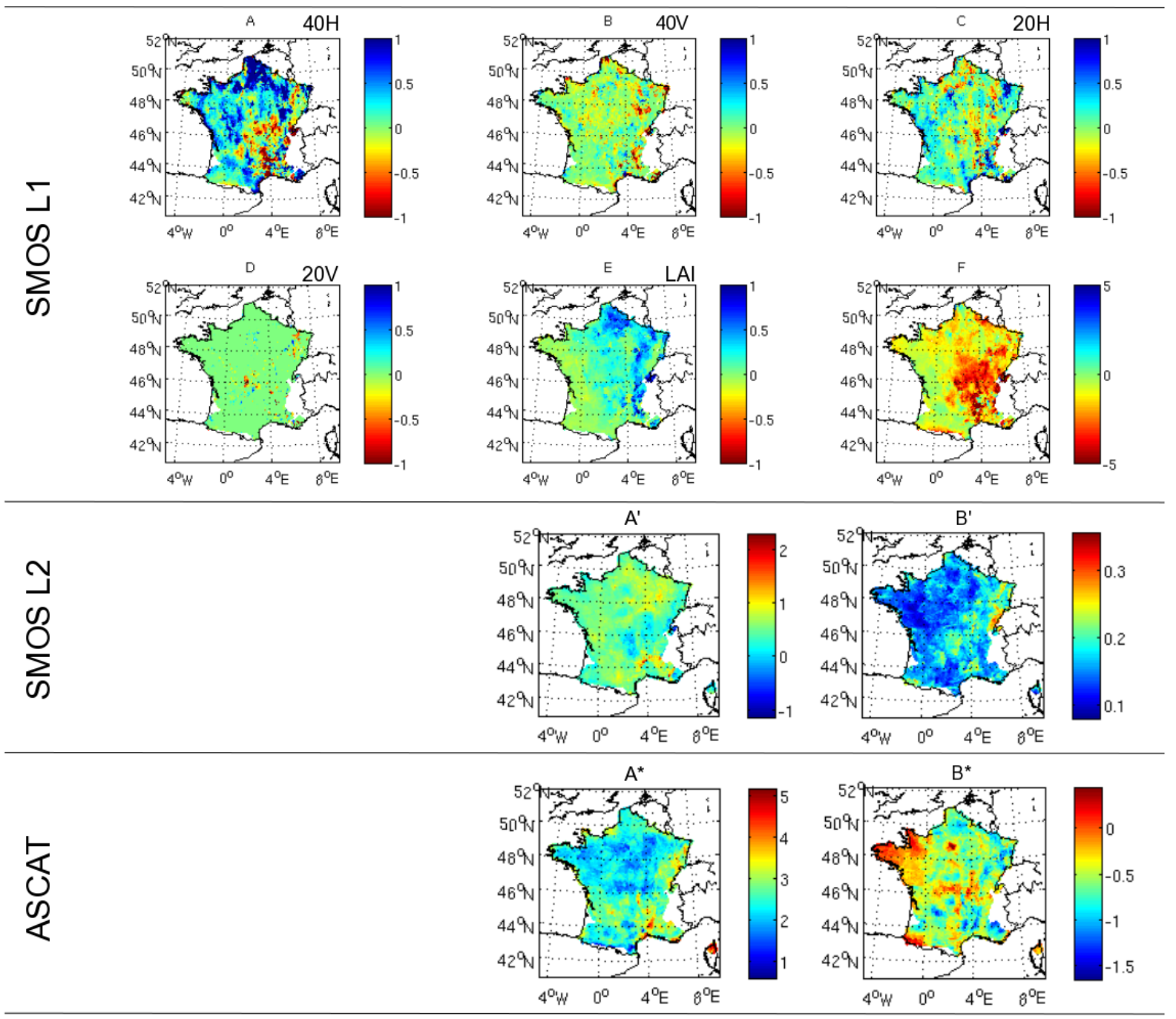

Fig. 8. Regression coefficients of satellite vs. ISBA-A-gs SSM in 2010: (top panels) SMOS-L1 with Eq. (2), (middle panels) SMOS-L2 with Eq. (3), (bottom panels) ASCAT with Eq. (4).

and the $B^{*}$ coefficient is observed $(r=0.07)$. This result shows the impact of topography on the SMOS signal.

\section{Discussion}

The comparison of SMOS and ASCAT SSM estimates with independent SSM observations and simulations over France in Figs. 3 and 5 shows that, overall, better results are obtained with ASCAT. Brocca et al. (2011) analysed the performance of the ASCAT SSM over various European regions, including in southern France, using three SMOSMANIA stations (URG, PRG and LZC). For the latter, their results are consistent with the results presented in this study. Apart from the fact that the SMOS-L2 product is still in the evaluation phase, while the ASCAT SSM product exists since 2007 and benefits from the heritage of the ERS SSM product, key physical processes governing the SMOS and ASCAT measurements differ. They are discussed below.

\subsection{Impact of the sampling depth}

In this study, three soil moisture datasets are considered along with the SMOS-L2 product: the ASCAT SSM, the ISBA-A-gs SSM, and the in situ SMOSMANIA observations at a depth of $5 \mathrm{~cm}$. These different SSM estimates do not present the same sampling depth, and slight differences in sampling depth may affect the temporal variability of SSM in response to rainfall events. As observed by Albergel et al. (2010), the ASCAT SSM product better correlates with LSM simulations representing a skin surface soil moisture, than with in situ observations at $5 \mathrm{~cm}$. This is not true for the SMOS-L2 SSM, as it presents a correlation with LSM simulations similar to its correlation with in situ observations at 
Table 3. Comparison between the in situ SSM and the SSM retrieved from the SMOS-L1 $T_{\mathrm{b}}$ using the regression coefficients $(A, B, C, D$, $E, F)$ of Eq. (2) derived from the in situ SSM: number of points used in the regression $(n)$, correlation coefficient $\left(r_{\mathrm{abs}}\right)$, root mean square error (RMSE) and p-value. The fraction of missing data caused by the RFI filtering is indicated. NS stands for non significant, and *, **, *** stand for p-values greater than 0.05 , between 0.05 and 0.001 , and between 0.001 and 0.0001 , respectively.

\begin{tabular}{|c|c|c|c|c|c|c|c|c|c|c|c|c|}
\hline Stations & $n$ & $r_{\mathrm{abs}}$ & $\operatorname{RMSE}\left(\mathrm{m}^{3} \mathrm{~m}^{-3}\right)$ & $\mathrm{p}$-value & $A$ & $B$ & $C$ & $D$ & E & $F$ & Altitude (m) & $\%$ of missing data \\
\hline SBR & - & - & - & - & - & - & - & - & - & - & 74 & - \\
\hline URG & 37 & 0.88 & 0.054 & $* * *$ & 0.6645 & 0.0567 & 0.0816 & 0 & -0.1050 & 0.9251 & 135 & 39 \\
\hline CRD & 43 & 0.82 & 0.030 & $* * *$ & 0.4343 & 0.0752 & 0.1428 & 0 & -0.0971 & -0.2683 & 149 & 36 \\
\hline PRG & 43 & 0.72 & 0.043 & $* * *$ & 0.4427 & 0.1198 & -0.0624 & 0 & -0.0675 & -0.2289 & 183 & 33 \\
\hline CDM & 40 & 0.74 & 0.048 & $* * *$ & 0.1862 & 0.1101 & 0.2234 & 0 & -0.0171 & 0.0706 & 118 & 34 \\
\hline LHS & 35 & 0.67 & 0.064 & $* * *$ & 0.2776 & 0.0631 & 0.1676 & 0 & -0.0237 & -0.0684 & 207 & 35 \\
\hline SVN & 33 & 0.83 & 0.069 & $* * *$ & 0.2985 & 0.0012 & 0.3377 & 0 & -0.0918 & 0.6340 & 122 & 39 \\
\hline MNT & 42 & 0.73 & 0.066 & $* * *$ & 0.5533 & 0.0704 & 0.2049 & 0 & 0.0680 & 0.5692 & 255 & 35 \\
\hline SFL & 39 & 0.79 & 0.043 & $* * *$ & 0.5107 & 0.0083 & 0.1568 & 0 & -0.0066 & 0.0053 & 236 & 39 \\
\hline MTM & 26 & 0.77 & 0.032 & $* * *$ & 0.2608 & -0.0344 & 0.1580 & 0 & -0.0095 & -0.6162 & 499 & 31 \\
\hline LZC & - & - & - & - & - & - & - & - & - & - & 102 & - \\
\hline NBN & 43 & 0.81 & 0.039 & $* * *$ & 1.3620 & -0.0218 & 0.2924 & 0 & -0.1013 & 0.6836 & 33 & 33 \\
\hline PZN & 38 & 0.69 & 0.057 & $* * *$ & 2.4201 & 0.1508 & -0.0991 & 0 & -0.0864 & 1.3057 & 39 & 30 \\
\hline PRD & 16 & 0.89 & 0.049 & $* * *$ & -0.7565 & 0.8619 & -0.0251 & 0 & -0.2245 & -0.8958 & 99 & 40 \\
\hline LGC & 13 & 0.49 & 0.034 & NS & 0.9649 & 0.3521 & -0.5398 & 0 & -0.0883 & -0.2759 & 436 & 63 \\
\hline MZN & - & - & - & - & - & - & - & - & - & - & 1165 & - \\
\hline VLV & 22 & 0.86 & 0.055 & $* * *$ & 1.6293 & 0.1919 & 0.1118 & 0 & -0.2052 & 2.2735 & 51 & 83 \\
\hline BRN & - & - & - & - & - & - & - & - & - & - & 672 & - \\
\hline MJN & 10 & 0.75 & 0.082 & $*$ & 0.3015 & 0.2545 & -0.1205 & 0 & -0.1796 & 0.1262 & 268 & 69 \\
\hline BRZ & - & - & - & - & - & - & - & - & - & - & 540 & - \\
\hline CBR & 13 & 0.65 & 0.069 & $*$ & 1.0116 & 0.9940 & 0.0994 & 0 & 0.1113 & 1.1543 & 584 & 68 \\
\hline
\end{tabular}

SMOS L1

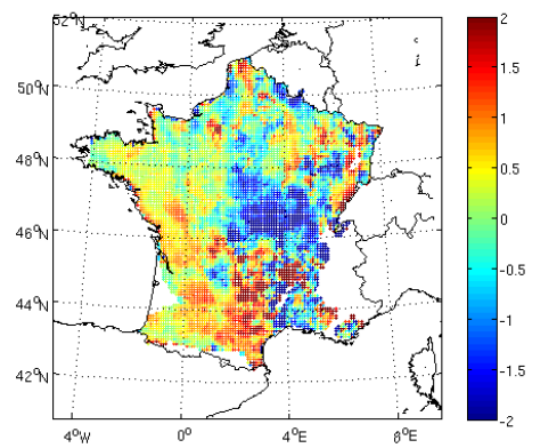

SMOS L2

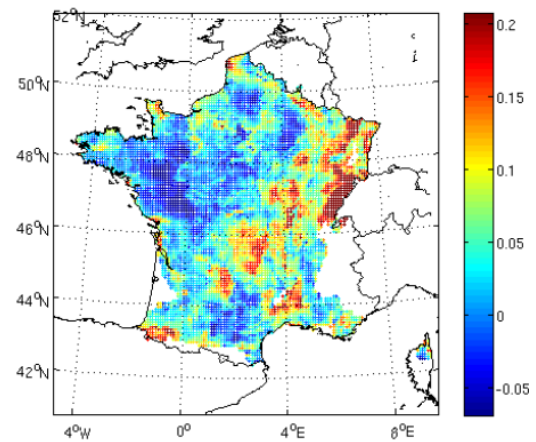

ASCAT

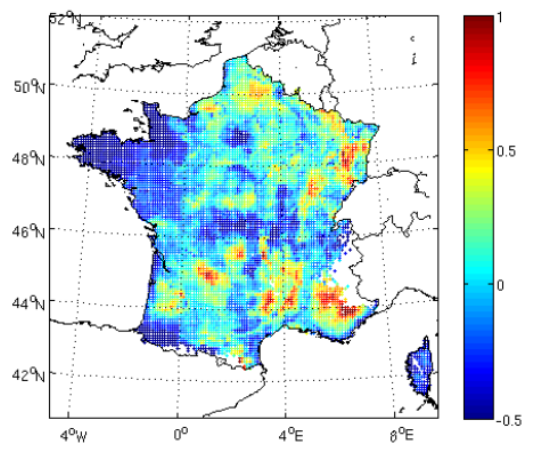

Fig. 9. Residual term of the regression equation of (left panel) SMOS-L1 F, (centre panel) SMOS-L2 $B^{\prime}$, (right panel) $B^{*}$ intercepts vs. altitude $(Z)$.

$5 \mathrm{~cm}$. Indeed, in both cases, the average temporal correlation at the location of the 21 SMOSMANIA stations is equal to 0.36 . More research is needed to analyse the soil sampling depth at L-band and C-band, using a multi-layer soil hydrology scheme.

\subsection{Topography and other geographical factors}

The impact of a marked topography can be explained by multiple local incidence angles caused by the different slopes of mountainous areas, affecting the $T_{\mathrm{b}}$ values and, consequently, the SSM retrievals. Mialon et al. (2008) have shown that relief features can cause $T_{\mathrm{b}}$ variations of up to $5 \mathrm{~K}$.
Sect. 3.2.2 show that this effect is visible in the SMOS products, both in the SSM derived from the SMOS-L1 data and in the SMOS-L2 data, using the intercept coefficients of Eqs. (2) and (3), $F$ and $B^{\prime}$, respectively. It must be noted that the fact that $F$ correlates better with topography than $B^{\prime}$ ( $r$ values of -0.51 and 0.37 , respectively) could denote an impact of topography on ancillary LAI and $T_{\text {eff }}$ information used in Eq. (2).

In order to search for other possible perturbing factors, an analysis of $F$ and $B^{\prime}$ intercepts was performed. A linear regression between the altitude of each grid-cell $(Z)$ and the intercepts was computed. The same analysis was applied to the ASCAT $B^{*}$ term. The residual terms of the regressions 
are shown in Fig. 9. In the three cases, some topography features still appear in the residual term (e.g. the Vosges). This may denote a non-linear impact of $Z$ on SSM retrievals. Moreover, for SMOS-L1, the area corresponding to the eastern SMOSMANIA stations (from Narbonne (NBN) to CBR) presents small scale variations which could denote the presence of RFI.

\subsection{Use of the SMOS-L1 product}

The results presented in Sect. 3.2.2 show that calibrating statistical relationships based on reference SSM values produced by a LSM permits to produce SSM estimates from the SMOS-L1 product. The scores of the calibrated statistical models are probably the best achievable scores over France using SMOS data, and the SMOS-L1 SSM outperforms the SMOS-L2 SSM: (1) for the SMOSMANIA in situ observations, the mean temporal absolute correlations of the two SSM estimates are 0.75 and 0.49 , respectively, (2) for the LSM simulations over France, the mean temporal correlations of the anomalies of the two SSM estimates are 0.44 and 0.40 , respectively. The use of Eq. (2) requires several SMOS-L1 configurations and this tends to reduce the number of points used for testing the regression. For the 12 western stations and for the 9 new eastern stations, on average, 38 and 19 points are used, respectively (Table 3 ). The p-value columns of Table 3 permit the assessment of the relevance of the empirical regression Eq. (2). It must be noted that the SMOSMANIA network observations is a long-term monitoring effort and this will allow the consolidation of the results of this study using longer SMOS time series. The derivation of SSM from SMOS $T_{\mathrm{b}}$ data by the use of regressed empirical logarithmic equations is a simple statistical way to retrieve SSM. As shown in this study over France, the application of Eq. (2) over large areas requires additional information provided by a land surface model. A priori, there is no obstacle to the extension of this technique at a global scale. The LAI can be either computed by a land surface model or derived from satellite observations. It must be noted that the regression coefficients found over France cannot be directly extrapolated to other areas. Nevertheless, France presents a large variety of soils and vegetation types, various climatic regions, also, which permits the validation of the approach. Also, these regression coefficients may depend on the used SMOS-L1 version, and may have to be updated from one version to another.

This result shows that Eq. (2) could be used in the assimilation of SMOS-L1 data in LSM. Indeed, SSM observations need to be rescaled to fit the model climatology, before being assimilated (Reichle and Koster, 2004; Draper et al., 2011b), and Eq. (2) could be used during this phase. Li et al. (2012) have tested the assimilation of AMSR-E soil moisture retrievals, in units of $\mathrm{m}^{3} \mathrm{~m}^{-3}$, without removing the systematic biases with the land surface model. In practise, this is a difficult exercise as the SSM climatology is model-dependent to a large extent, and the simulated root-zone soil moisture has to be consistent with the surface fluxes (e.g. evapotranspiration). Using a wrong SSM climatology tends to bias the assimilation and to force the analysed variable (e.g. the rootzone soil moisture) towards unrealistic estimates (e.g. of the soil water content available for plant transpiration). This bias problem was discussed by Calvet et Noilhan (2000) and by Reichle and Koster (2004).

\subsection{RFI and impact of the sampling time}

An important difference between SMOS and ASCAT is the number of satellite observations that are available for the two sensors. From Table 2, on average, it is equal to 87 and 141 for SMOS and ASCAT, respectively. Table 3 shows that a higher fraction of SMOS-L1 data are affected by RFI for the eastern SMOSMANIA stations (LGC, MZN, VLV, BRN, Méjannes-le-Clap (MJN), BRZ, CBR), with more than $60 \%$ missing data. For MZN, BRN and BRZ, less than 10 observations were available, and the regression model was not applied. Apart from VLV, p-values higher than 0.001 are observed. For the whole SMOSMANIA network, $55 \%$ of the observations had to be removed, on average. In spite of the filtering procedure described in Sect. 2.1.1 and in Sect. 2.4.2, the SMOS data could be affected by undetected low-level RFI.

Calvet and Noilhan (2000) and Pellarin et al. (2006) have discussed the impact of the sampling time on root-zone soil moisture retrievals. They showed that a sampling time of $3 \mathrm{~d}$ (or better) is needed. In Tables 2 and 3, the number of satellite data corresponds to the data that were actually used, after RFI filtering. Indeed, in some regions, many SMOS data are lacking due to RFI. On average for the whole of France, for the year 2010, 122 SMOS-L2 and 187 ASCAT morning SSM observations can be used. These numbers correspond to an average effective sampling time of $3 \mathrm{~d}$ for SMOS and $1.95 \mathrm{~d}$ for ASCAT. Note that for the 9 new stations of the SMOSMANIA network (Table 1), in the Mediterranean region, the average effective sampling time of SMOS-L2 is $5.9 \mathrm{~d}$, only. For the 12 western stations of the network, the SMOS-L2 sampling time (3.4d) is closer to the average value of $3 \mathrm{~d}$.

\subsection{Monitoring of future SSM product versions}

This study shows that the in situ SSM observations performed by the SMOSMANIA network have potential to monitor the quality of satellite derived SSM products, and to benchmark distinct SSM products across contrasting geological and climatic conditions. In addition to this network, the high resolution $(8 \mathrm{~km} \times 8 \mathrm{~km})$ ISBA-A-gs model, forced by in situ precipitation data can be used to extend the SMOSMANIA monitoring capacity to the whole metropolitan France. The 2010 SMOS-L2 data used in this study are based on the very first SSM product derived from SMOS. Improved reprocessed SMOS-L2 data will be produced in 
the future, and the reference SSM data used in this study will contribute to quantify the added value of the new versions. This is true for ASCAT, also. In a recent study, Albergel et al. (2012) have used the SMOSMANIA data to benchmark the SMOS and ASCAT SSM products. While they used the first version of the ASCAT SSM product provided by EUMETSAT, based on the ERS algorithm, an updated version was used in this study (Sect. 2.1.2). For the 12 westernmost, and for the 9 eastern SMOSMANIA stations, the mean absolute correlation scores obtained by Albergel et al. (2012) for ASCAT are 0.52 and 0.33 , respectively. In this study, the corresponding score values are 0.71 and 0.53 , respectively. Although the considered data set is not exactly the same (we used morning observations, only, while Albergel et al. (2012) used the pooled morning and evening observations), it can be concluded that much better results are obtained with the updated ASCAT SSM product. The good correlations found using the upgraded ASCAT product are consistent the findings of Brocca et al. (2010b) and Draper et al. (2011), based on the same product.

\section{Conclusion}

In this study, the first SMOS L1 and L2 products were compared with another satellite soil moisture product, the ASCAT SSM, over France. Independent SSM estimates, derived from either in situ observations in southern France, or LSM simulations over the whole of France, were used to perform a multiple comparison with the satellite products. Although SMOS and ASCAT do not use the same measurement technique, nor the same microwave frequency, consistent results were found, especially in wet conditions. On the other hand, a number of differences was evidenced. In particular, the soil sampling depth is deeper in the SMOS measurements, and this affected the correlation of the SMOS-L2 product with the skin SSM simulated by the ISBA-A-gs LSM. Also, perturbing geographic spatial patterns such as topography could be extracted from the SMOS-L1 and SMOS-L2 products, and, to a lesser extent, from the ASCAT SSM.

Overall, the ASCAT SSM outperformed the SMOS-L2 product. As the quality of the SMOS products is affected by RFI, this conclusion is valid for the RFI intensity observed in France, and more work is needed to benchmark the SSM products in other areas.

The findings of Albergel et al. (2011) that simple regression equations can be applied across scales on the SMOSL1 product, was confirmed for the whole of France, in contrasted surface conditions. This method could offer a simple way to ingest SMOS data into LSM using data assimilation techniques.
Acknowledgements. The work of M. Parrens was supported by Université Paul Sabatier, Toulouse. The work of E. Zakharova was supported by the STAE (Sciences et Technologies pour l'Aéronautique et l'Espace) foundation, in the framework of the CYMENT project, and by the "Programme Terre Océan Surface Continentales et Atmosphère" (TOSCA, CNES). The work of S. Lafont, was supported by the GEOLAND2 project, co-funded by the European Commission within the GMES initiative in FP7. W. Wagner acknowledges the support of the Austrian Space Applications Programme (ASAP) and EUMETSAT for the ASCAT data processing.

Edited by: A. Loew

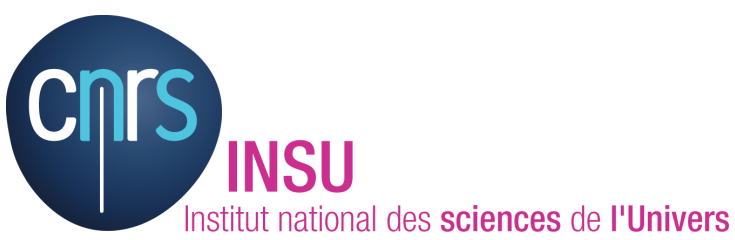

The publication of this article is financed by CNRS-INSU.

\section{References}

Albergel, C., Rüdiger, C., Pellarin, T., Calvet, J.-C., Fritz, N., Froissard, F., Suquia, D., Petitpa, A., Piguet, B., and Martin, E.: From near-surface to root-zone soil moisture using an exponential filter: an assessment of the method based on in-situ observations and model simulations, Hydrol. Earth Syst. Sci., 12, 1323-1337, doi:10.5194/hess-12-1323-2008, 2008.

Albergel, C., Rüdiger, C., Carrer, D., Calvet, J.-C., Fritz, N., Naeimi, V., Bartalis, Z., and Hasenauer, S.: An evaluation of ASCAT surface soil moisture products with in-situ observations in Southwestern France, Hydrol. Earth Syst. Sci., 13, 115-124, doi:10.5194/hess-13-115-2009, 2009.

Albergel, C., Calvet, J.-C., de Rosnay, P., Balsamo, G., Wagner, W., Hasenauer, S., Naeimi, V., Martin, E., Bazile, E., Bouyssel, F., and Mahfouf, J.-F.: Cross-evaluation of modelled and remotely sensed surface soil moisture with in situ data in southwestern France, Hydrol. Earth Syst. Sci., 14, 2177-2191, doi:10.5194/hess-14-2177-2010, 2010.

Albergel, C., Zakharova, E., Calvet, J.-C., Zribi, M., Pardé, M., Wigneron, J.-P., Novello, N., Kerr, Y., Mialon, A., and Fritz, N.: A first assessment of the SMOS data in southwestern France using in situ and airborne soil moisture estimates: the CAROLS airborne campaign, Remote Sens. Environ., 115, 2718-2728, doi:10.1016/j.rse.2011.06.012, 2011.

Albergel, C., de Rosnay, P., Gruhier, C., Muñoz-Sabater, J., Hasenauer, S., Isaksen, L., Kerr, Y., and Wagner, W.: Evaluation of remotely sensed and modelled soil moisture products using global ground-based in situ observations, Remote Sens. Environ., 118, 215-226, doi:10.1016/j.rse.2011.11.017, 2012.

Attema, E. W. P.: The active microwave instrument onboard the ERS-1 satellite, Proc. IEEE, 79, 791-799, 1991. 
Bartalis, Z., Hasenauer, S., Naeimi, V., and Wagner, W.: WARPNRT 2.0 Reference Manual, ASCAT Soil Moisture Report Series, No. 14, Institute of Photogrammetry and Remote Sensing, Vienna University of Technology, Austria, 26, 2007a.

Bartalis, Z., Wagner, W., Naeimi, V., Hasenauer, S., Scipal, K., Bonekamp, H., Figa, J., and Anderson, C.: Initial soil moisture retrievals from the METOP-A advanced Scatterometer (ASCAT), Geophys. Res. Lett., 34, L20401, doi:10.1029/2007GL031088, 2007b.

Beljaars, A., Viterbo, P., Miller, M., and Betts, A.: The anomalous rainfall over the United States during July 1993: sensitivity to land surface parameterization and soil moisture anomalies, Mon. Weather Rev., 124, 362-383, 1996.

Boone, A. and Etchevers, P.: An inter-comparison of three snow schemes of varying complexity coupled to the same land-surface model: local scale evaluation at an Alpine site, J. Hydrometeorol., 2, 374-394, 2001.

Boone, A., Calvet, J.-C., and Noilhan, J.: Inclusion of a third soil layer in a land surface scheme using the force-restore method, $\mathrm{J}$. Appl. Meteorol., 38, 1611-1630, 1999.

Brocca, L., Melone, F., Moramarco, T., Wagner, W., and Hasenauer, S.: ASCAT soil wetness index validation through in-situ and modeled soil moisture data in central Italy, Remote Sens. Environ., 114, 2745-2755, 2010b.

Brocca, L., Melone, F., Moramarco, T., Wagner, W., Naeimi, V., Bartalis, Z., and Hasenauer, S.: Improving runoff prediction through the assimilation of the ASCAT soil moisture product, Hydrol. Earth Syst. Sci., 14, 1881-1893, doi:10.5194/hess-141881-2010, 2010a.

Brocca, L., Hasenauer, S., Lacava, T., Melone, F., Moramarco, T., Wagner, W., Dorigo, W., Matgen, P., Martinez-Fernandez, J., Llorens, P., Latron, J., Martin, C., and Bittelli, M.: Soil moisture estimation through ASCAT and AMSR-E sensors: an intercomparison and validation study across Europe, Remote Sens. Environ., 12, 3390-3408, doi:10.1016/j.rse.2011.08.003, 2011.

Calvet, J.-C. and Noilhan, J.: From near-surface to root-zone soil moisture using yearround data, J. Hydrometeorol., 1, 393-411, 2000.

Calvet, J.-C., Noilhan, J., Roujean, J.-L., Bessemoulin, P., Cabelguenne, M., Olioso, A., and Wigneron, J.-P.: An interactive vegetation SVAT model tested against data from six contrasting sites, Agr. Forest Meteorol., 92, 73-95, 1998.

Calvet, J.-C., Fritz, N., Froissard, F., Suquia, D., Petitpa, A., and Piguet, B.: In-situ soil moisture observations for the CAL/VAL of SMOS: the SMOSMANIA network, International Geoscience and Remote Sensing Symposium, IGARSS, Barcelona, Spain, 1196-1199, doi:10.1109/IGARSS.2007.4423019, 2328 July 2007.

Calvet, J.-C., Wigneron, J.-P., Walker, J., Karbou, F., Chanzy, A., and Albergel, C.: Sensitivity of passive microwave observations to soil moisture and vegetation water content: Lband to W-band, IEEE T. Geosci. Remote., 49, 1190-1199, doi:10.1109/TGRS.2010.2050488, 2011.

Chanzy, A., Schmugge, T. J., Calvet, J.-C., Kerr, Y., van Oevelen, P., Grosjean, O., and Wang, J. R.: Airborne microwave radiometry on a semi-arid area during HAPEX-Sahel, J. Hydrol., 188-189, 285-309, 1997.
Cleveland, W. S. and Devlin, S. J.: Locally-Weighted Regression: An approach to regression analysis by local fitting, J. Am. Stat. Assoc., 83, 596-610, doi:10.2307/2289282, 1988.

Deardorff, J. W.: Efficient prediction of ground surface temperature and moisture with inclusion of a layer of vegetation, J. Geophys. Res., 83, 1889-1903, 1978.

De Wit, A. J. and van Diepen, A. J.: Crop model data assimilation with the ensemble Kalman filter for improving regional crop yield forecasts, Agr. Forest Meteorol., 146, 38-56, 2007.

Diermeyer, P. A.: Using a global soil wetness dataset to improve seasonal climate simulation, J. Climate, 13, 2900-2922, 2000.

Dirmeyer, P. A., Dolman, A. J., and Sato, N.: The pilot phase of the global soil wetness project, B. Am. Meteorol. Soc., 80, 851-878, 1999.

Dorigo, W. A., Wagner, W., Hohensinn, R., Hahn, S., Paulik, C., Xaver, A., Gruber, A., Drusch, M., Mecklenburg, S., van Oevelen, P., Robock, A., and Jackson, T.: The International Soil Moisture Network: a data hosting facility for global in situ soil moisture measurements, Hydrol. Earth Syst. Sci., 15, 1675-1698, doi:10.5194/hess-15-1675-2011, 2011

Draper, C., Mahfouf, J.-F., Calvet, J.-C., Martin, E., and Wagner, W.: Assimilation of ASCAT near-surface soil moisture into the SIM hydrological model over France, Hydrol. Earth Syst. Sci., 15, 3829-3841, doi:10.5194/hess-15-3829-2011, 2011a.

Draper, C. S., Mahfouf, J.-F., and Walker, J. P.: Root zone soil moisture from the assimilation of screen-level variables and remotely sensed soil moisture, J. Geophys. Res., 116, D02127, doi:10.1029/2010JD013829, 2011b.

Durand, Y., Brun, E., Merindol, L., Guyomarc'h, G., Lesaffre, B. and Martin, E.: A meteorological estimation of relevant parameters for snow models, Ann. Geophys., 18, 65-71, 1993.

Durand, Y., Giraud, G., Brun, E., Merindol, L., and Martin, E.: A computer-based system simulating snow-pack structures as a tool for regional avalanche forecasting, Ann. Glaciol., 45, 469-484, 1999.

Eagleman, J. R. and Lin, W. C.: Remote sensing of soil moisture by a 21-cm passive radiometer, J. Geophys. Res., 81, 3660-3666, 1976

Eltahir, E. A. B.: A soil moisture rainfall feedback mechanism 1 Theory and observations, Water Resour. Res., 34, 765-776, 1998.

Faroux, S., Roujean, J.-L., Kaptué, A., and Masson, V.: La base de données de paramètres de surface ECOCLIMAP-II sur l'Europe, Note de centre du Groupe de Météorologie à Moyenne Echelle, 86, Météo-France, CNRM, Toulouse, France, 120 pp., 2009.

Fennessy, M. J. and Shukla, J.: Impact of initial soil wetness on seasonal atmospheric prediction, J. Climate, 12, 3167-3180, 1999.

Georgakakos, K. P. and Carpenter, M.: Potential value of operationally available and spatially distributed ensemble soil water estimates for agriculture, J. Hydrol., 328, 177-191, 2006.

Guerif, M. and Duke, C. I.: Adjustment procedures of a crop model to the site-specific characteristics of soil and crop using remote sensing data assimilation, Agr. Ecosyst. Environ., 81, 57-69, 2000.

Jackson, T., Le Vine, D., Swift, C., Schmugge, T., and Schiebe, F.: Large area mapping of soil moisture using the ESTAR passive microwave radiometer in Washita92, Remote Sens. Environ., 53, 27-37, 1995 
Jackson, T. J.: Profile soil moisture from space measurements, J. Irrig. Drain. Div.-ASCE, 106, 81-92, 1980.

Jackson, T. J., Hsu, A. Y., van de Griend, A., and Eagleman, J. R.: Skylab L band microwave radiometer observations of soil moisture revisited, Int. J. Remote Sens., 25, 2585-2606, 2004.

Kerr, Y.: Soil moisture from space: Where are we?, Hydrogeol. J., 15, 117-120, 2007.

Kerr, Y.: SMOS level 2 Processor for Soil Moisture, Algorithm Theoretical Basis Document (ATBD), 133 pp., 2010.

Kerr, Y. H. and Njoku, E. G.: On the use of passive microwave at $37 \mathrm{GHz}$ in remote sensing of vegetation, Int. J. Remote Sens., 14, 1931-1943, 1993.

Kerr, Y., Waldteufel, P., Wigneron, J.-P., Martinuzzi, J.-M., Font, J., and Berger, M.: Soil Moisture retrieval from space: the Soil Moisture and Ocean Salinity (SMOS) mission, IEEE T. Geosci. Remote, 39, 1729-1736, 2001.

Le Moigne, P.: SURFEX scientific documentation. Note de centre du Groupe de Météorologie à Moyenne Echelle, 87, available online at: http://www.cnrm.meteo.fr/surfex/, last access: September 2011, Météo-France, CNRM, Toulouse, France, 211 pp., 2009.

Ledoux, E., Girard, G., De Marsily, G., and Deschenes, J.: Spatially distributed modeling: Conceptual approach, coupling surface water and ground-water, in: Unsaturated Flow Hydrologic Modeling: Theory and Practice, NATO ASI Series C, vol. 275, edited by: Morel-Seytoux, H. J., 435-454, Kluwer Acad., Norwell, Mass., 1989.

Li, B., Toll, D., Zhan, X., and Cosgrove, B.: Improving estimated soil moisture fields through assimilation of AMSR-E soil moisture retrievals with an ensemble Kalman filter and a mass conservation constraint, Hydrol. Earth Syst. Sci., 16, 105-119, doi:10.5194/hess-16-105-2012, 2012.

Masson, V., Champeaux, J. L., Chauvin, F., Meriguet, C., and Lacaze, R.: A global database of land surface parameters at $1 \mathrm{~km}$ resolution in meteorological and climate models, J. Climate, 16, 1261-1282, 2003.

Mattar, C., Wigneron, J.-P., Sobrino, J. A., Novello, N., Calvet, J.-C., Albergel, C., Richaume, P., Mialon, A., Guyon, D., Jiménez-Muñoz, J. C., and Kerr, Y.: A combined optical-microwave method to retrieve soil moisture over vegetated areas, IEEE Trans. Geosci. Remote. Sens., doi:10.1109/TGRS.2011.2179051, in press, 2012.

McMullan, K. D., Martin-Neira, M., Hahne, A., and Borges, A.: SMOS-Earth's Water Monitoring Mission, Space Technologies for the Benefit of Human Society and Earth, Part I, 2009.

Mialon, A., Coret, L., Kerr, Y., Sécherre, F., and Wigneron, J.-P.: Flagging the topographic impact on the SMOS signal, IEEE T. Geosci. Remote., 46, 689-694, 2008.

Njoku, E. G., Ashcroft, P., Chan, T. K., and Li, L.: Global survey and statistics of radiofrequency interference in AMSR-E land observation, IEEE T. Geosci. Remote, 43, 938-947, 2005.

Noilhan, J. and Mahfouf, J.-F.: The ISBA land surface parameterisation scheme, Global Planet. Change, 13, 145-149, 1996.

Noilhan, J. and Planton, S.: A simple parameterisation of land surface processes for meteorological model, Mon. Weather Rev., 117, 356-549, 1989.
Oliva, R., Daganzo, E., Kerr, Y., Mecklenburg, S., Nieto, S., Richaume, P., and Gruhier, C.: SMOS radio frequency interference scenario: status and actions taken to improve the RFI environment in the $1400-1427 \mathrm{MHz}$ passive band, IEEE T. Geosci. Remote, doi:10.1109/TGRS.2012.2182775, in press, 2012.

Panciera, R., Walker, J. P., Kalma, J. D., Kim, E. J., Saleh, K., and Wigneron, J.-P.: Evaluation of the SMOS L-MEB passive microwave soil moisture retrieval algorithm, Remote Sens. Environ., 113, 435-444, 2009.

Pardé, T., Zribi, M., Fanise, P., and Dechambre, M.: Analysis of RFI issue using the CAROLS L-band experiment, IEEE T. Geosci. Remote, 49, 1063-1070, 2011.

Pellarin, T., Calvet, J.-C., and Wigneron, J.-P.: Surface soil moisture retrieval from L-band radiometry: a global regression study, IEEE T. Geosci. Remote, 41, 2037-2051, 2003a.

Pellarin, T., Wigneron, J.-P., Calvet, J.-C., Berger, M., Douville, H., Ferrazzoli, P., Kerr, Y. H., Lopez-Baeza, E., Pulliainen, J., Simmonds, L. P., and Waldteufel, P.: Two-year global simulation of L-band brightness temperatures over land, IEEE T. Geosci. Remote, 41, 2135-2139, 2003b.

Pellarin, T., Wigneron, J.-P., Calvet, J.-C., and Waldteufel, P.: Global soil moisture retrieval from a synthetic L-band brightness temperature data set, J. Geophys. Res., 108, 4364, doi:10.1029/2002JD003086, 2003c.

Pellarin, T., Calvet, J.-C., and Wagner, W.: Evaluation of ERS scatterometer soil moisture products over a half-degree region in southwestern France, Geophys. Res. Lett., 33, L17401, doi:10.1029/2006GL027231, 2006.

Raju, S., Chanzy, A., Wigneron, J.-P., Calvet, J.-C., Kerr, Y., and Laguerre, L.: Soil moisture and temperature profile effects on microwave emission at low frequencies, Remote Sens. Environ., 54, 85-97, 1995.

Reichle, R. and Koster, R.: Bias reduction in short records of satellite soil moisture, Geophys. Res. Lett., 31, L19501, doi:10.1029/2004GL020938, 2004.

Robock, A., Vinnikov, K. Y., Srinivasan, J. K., Entin, J. K., Hollinger, S. E., Sperenskaya, N. A., Liu, S., and Namkhai, A.: The global soil moisture data bank, B. Am. Meteorol. Soc., 81, 1281-1299, 2000

Rüdiger, C., Hancock, G., Hemakumara, H. M., Jacobs, B., Kalma, J. D., Martinez, C., Thyer, M., Walker, J. P., Wells, T., and Willgoose, G. R.: Goulburn River experimental catchment data set, Water Resour. Res., 43, W10403, doi:10.1029/2006WR005837, 2007.

Rüdiger, C., Calvet, J.-C., Gruhier, C., Holmes, T., De Jeu, R., and Wagner, W.: An intercomparison of ERS-Scat and AMSR-E soil moisture observations with model simulations over France, J. Hydrometeorol., 10, 431-447, doi:10.1175/2008jhm997.1, 2009.

Saleh, K., Wigneron, J.-P., Calvet, J.-C., Lopez-Baeza, E., Ferrazzoli, P., Berger, M., Wursteisen, P., Simmonds, L., and Miller, J.: The EuroSTARRS airborne campaign in support of the SMOS mission: First results over land surfaces, Int. J. Remote Sens., 25, 177-194, 2004.

Saleh, K., Wigneron, J.-P., de Rosnay, P., Calvet, J.-C., Escorihuela, M. J., Kerr, Y., and Waldteufel, P.: Impact of rain interception by vegetation and mulch on the L-band emission of natural grass, Remote Sens. Environ., 101, 127-139, 2006a. 
Saleh, K., Wigneron, J.-P., de Rosnay, P., Calvet, J.-C., and Kerr, Y.: Semi-empirical regressions at L-band applied to surface soil moisture retrieval over grass, Remote Sens. Environ., 101, 415426, 2006b.

Schmugge, T. J.: Remote Sensing of Soil Moisture: Recent Advances, IEEE T. Geosci. Remote, GE21, 145-146, 1983.

Schmugge, T. J.: Applications of passive microwave observations of surface soil moisture, J. Hydrol., 212-213, 188-197, 1998

Skou, N.: Microwave radiometer systems: design and analysis, MA, Norwood, USA, Artech House, 1989.

Ulaby, F. T., Moore, R. K., and Fung, A. K.: Physical mechanisms and empirical models for scattering and emission, in: Microwave Remote Sensing: Active and Passive (vol. II), Artech House, Boston, MA, USA, 816-921, 1982.

Ulabay, F., Moore, R., and Fung, A.: Microwave Remote Sensing: Active and Passive, From Theory to Application, Artech House, Norwwod, MA, 1986.

Wagner, W., Lemoine, G., Borgeaud, M., and Rott, H.: A study of vegetation cover effects on ERS scatterometer data, Geosci. Remote Sens., 37, 938-948, 1999a.

Wagner, W., Lemoine, G., and Rott, H.: A method for estimating soil moisture from ERS scatterometer and soil data, Remote Sens. Environ., 70, 191-207, 1999b.

Wagner, W., Noll, J., Borgeaud, M., and Rott, H.: Monitoring soil moisture over the Canadian prairies with the ERS scatterometer, IEEE T. Geosci. Remote, 37, 206-216, 1999c.

Wagner, W., Blöschl, G., Pampaloni, P., Calvet, J.-C., Bizzarri, B., Wigneron, J.-P., and Kerr, Y.: Operational readiness of microwave remote sensing of soil moisture for hydrologic applications, Nord. Hydrol., 38, 1-20, 2007.

Wigneron, J.-P., Chanzy, A., Calvet, J.-C., and Bruguier, N.: A simple algorithm to retrieve soil moisture and vegetation biomass using passive microwave measurements over crop fields, Remote Sens. Environ., 51, 331-341, 1995.
Wigneron, J.-P., Guyon, D., Calvet, J.-C., Courrier, G., and Bruguier, N.: Monitoring coniferous forest characteristics using a multifrequency $(5-90 \mathrm{GHz})$ microwave radiometer, Remote Sens. Environ., 60, 299-310, 1997.

Wigneron, J.-P., Calvet, J.-C., Pellarin, T., Van de Griend, A., Berger, M., and Ferrazzoli, P.: Retrieving near surface soil moisture from microwave radiometric observations: Current status and future plans, Remote Sens. Environ., 85, 489-506, 2003.

Wigneron, J.-P., Calvet, J.-C., de Rosnay, P., Kerr, Y., Waldteufel, P., Saleh, K., Escorihuela, M.-J., and Kruszewski, A.: Soil moisture retrievals from biangular L-band passive microwave observations, IEEE T. Geosci. Remote., 1, 277-281, 2004.

Wigneron, J.-P., Kerr, Y., Waldteufel, P., Saleh, K., Escorihuela, M.J., Richaume, P., Ferrazzoli, P., de Rosnay, P., Gurney, R., Calvet, J.-C., Grant, J. P., Guglielmetti, M., Hornbuckle, B., Mätzler, C., Pellarin, T., and Schwank, M.: L-band Microwave Emission of the Biosphere (L-MEB) Model: Description and calibration against experimental data sets over crop fields, Remote Sens. Environ., 107, 639-655, 2007.

Wigneron, J.-P., Chanzy, A., de Rosnay, P., Rüdiger, C., and Calvet, J.-C.: Estimating the effective soil temperature at L-band as a function of soil Properties, IEEE T. Geosci. Remote, 46, 797807,2008

Wilson, W. J., Yuech, S. H., Dinardo, S. J., Chazanoff, S. L., Kitiyakara, A., Li, F. K., and Rahmat-Samii, Y.: Passive active Lband and S-band (PALS) microwave sensor for ocean salinity and soil moisture measurements, IEEE T. Geosci. Remote, 39, 1039-1048, 2001.

Zribi, M., Pardé, M., Boutin, J., Fanise, P., Hauser, D., Dechambre, M., Kerr, Y., Leduc-Leballeur, M., Skou, M., Søbjærg, S. S., Albergel, C., Calvet, J.-C., Wigneron, J.-P., Lopez-Baeza, E., Ruis, A., and Tenerelli, J.: CAROLS: a new airborne L-band radiometer for ocean surface and land observations, Sensors, 11, 719-742, doi:10.3390/s110100719, 2011. 